
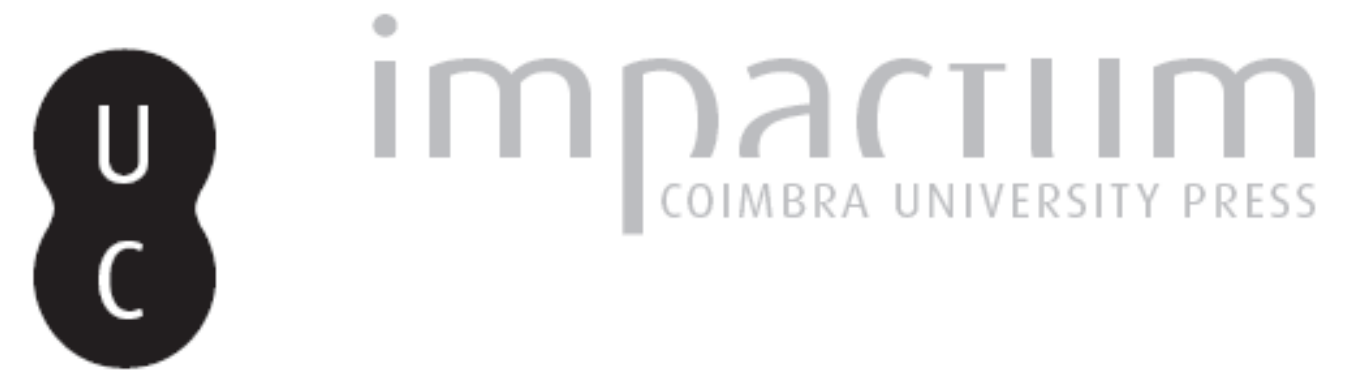

\title{
Povoados fortificados com pedras fincadas em Trás-os-Montes
}

Autor(es): $\quad$ Redentor, Armando

Publicado por: Imprensa da Universidade de Coimbra

URL persistente:

URI:http://hdl.handle.net/10316.2/45371

DOI:

DOI:https://dx.doi.org/10.14195/1647-8657_39_1

Accessed : $\quad$ 26-Apr-2023 11:14:10

A navegação consulta e descarregamento dos títulos inseridos nas Bibliotecas Digitais UC Digitalis, UC Pombalina e UC Impactum, pressupõem a aceitação plena e sem reservas dos Termos e Condições de Uso destas Bibliotecas Digitais, disponíveis em https://digitalis.uc.pt/pt-pt/termos.

Conforme exposto nos referidos Termos e Condições de Uso, o descarregamento de títulos de acesso restrito requer uma licença válida de autorização devendo o utilizador aceder ao(s) documento(s) a partir de um endereço de IP da instituição detentora da supramencionada licença.

Ao utilizador é apenas permitido o descarregamento para uso pessoal, pelo que o emprego do(s) título(s) descarregado(s) para outro fim, designadamente comercial, carece de autorização do respetivo autor ou editor da obra.

Na medida em que todas as obras da UC Digitalis se encontram protegidas pelo Código do Direito de Autor e Direitos Conexos e demais legislação aplicável, toda a cópia, parcial ou total, deste documento, nos casos em que é legalmente admitida, deverá conter ou fazer-se acompanhar por este aviso.

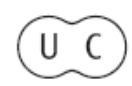


UNIVERSIDADE DE COIMBRA

FACULDADE DE LETRAS

\section{CONIMBRIGA}

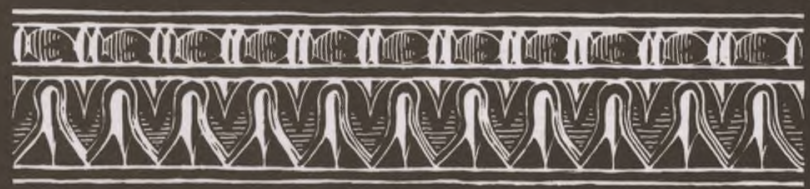

VOLUME XXXIX - 2000 


\section{ARMando Redentor}

Arqueólogo. Mestrando de Arqueologia Romana. Universidade de Coimbra

\section{POVOADOS FORTIFICADOS COM PEDRAS FINCADAS \\ EM TRÁS-OS-MONTES \\ "Conimbriga" XXXIX (2000) p. 5-51}

RESUMEN: Estuda-se a integração de barreiras de pedras fincadas nos sistemas defensivos dos povoados fortificados transmontanos, às quais não se atribui mais que um significado funcional, atendendo à sua relação com as restantes defesas dos povoados, à sua distribuição geográfica e cronologia.

Apesar de os dados cronológicos serem escassos, avança-se com a hipótese de, na parte oriental de Trás-os-Montes, o seu aparecimento ter acontecido no século VI a. C., enquanto que, para a parte ocidental, apenas se tem como segura a utilização deste sistema defensivo em povoados datáveis da época romana.

Em complemento, apresenta-se o inventário dos povoados fortificados transmontanos que dispõem (ou dispuseram) de campos de pedras fincadas.

ABSTRACT: The integration of chevaux-de-frise belts in the defensive systems of Trás-os-Montes hillforts is analysed. Given their relation with the remaining defensive systems of the fortifications as well as their geographical distribution and chronology, a funcional meaning is attributed to chevaux-de-frise.

In spite of the scarcity of chronological data, the hypothesis is put forward that chevaux-de-frise appeared in the eastern part of Trás-os-Montes in the VI century BC while in the western part their use can only be safely dated in Roman period hillforts.

As a complement, an inventory of the fortified settlements of Trás-os-Montes that include (or included) cheveaux-de-frise is presented. 
(Página deixada propositadamente em branco) 


\section{POVOADOS FORTIFICADOS COM PEDRAS FINCADAS EM TRÁS-OS-MONTES *}

\section{Nota introdutória}

$\mathrm{O}$ tema dos sistemas defensivos com pedras fincadas não tem merecido grande atenção por parte dos investigadores nacionais: descrevem-se povoados fortificados providos dessas particulares defesas, fazem-se referências pontuais ao tema, mas não existe qualquer trabalho recente exclusivamente a ele dedicado. O objectivo desta nossa reflexão é, assim, apresentar o estado actual dos conhecimentos relativos aos povoados fortificados com pedras fincadas de Trás-os-Montes.

$\mathrm{O}$ trabalho encontra-se organizado em duas partes principais, às quais se associa um inventário dos povoados fortificados que possuem (ou possuíram) este sistema defensivo. Numa primeira parte, reflectimos acerca do conceito de pedras fincadas enquanto engenho defensivo, da sua origem e cronologia e da sua função específica. Em seguida, analisamos o estado da questão relativamente ao território transmontano, nomeadamente no que concerne à sua distribuição geográfica, à sua integração no conjunto dos sistemas defensivos dos povoados e à sua cronologia.

Uma análise desta temática com outro fôlego apenas seria possível se dispuséssemos de mais e melhores dados estratigraficamente

* O presente artigo é, parcialmente, o resultado de um trabalho por nós apresentado no seminário "O Mundo Pré-romano de Portugal", do Mestrado em Arqueologia Romana, da Faculdade de Letras da Universidade de Coimbra. Expressamos o nosso agradecimento à Doutora Raquel Vilaça, pelo apoio e estímulo concedidos durante a sua elaboração.

Conimbriga, 39 (2000) 5-51 
contextualizados, e que, preferencialmente, também incidissem sobre os próprios campos de pedras fincadas. Restou-nos aproveitar, o melhor possível, a informação disponível.

2. As pedras fincadas como sistema defensivo

\subsection{As pedras fincadas como evidência arqueológica}

As pedras fincadas são simples blocos de pedra, colocados na vertical, próximos uns dos outros, formando um ou mais campos, ou barreiras, estrategicamente posicionados, combinando-se, frequentemente, com fossos e parapeitos ou existindo, tão só, junto ao pano de muralha, habitualmente voltados para os lados menos defensáveis. Morfologicamente, estes blocos, utilizando quer o granito quer o xisto, de acordo com a composição geológica do local, são diversos, mas é comum possuírem uma secção prismática, o topo ponteagudo e dimensões bastante irregulares.

A terminologia empregue pelos diversos investigadores que se têm ocupado do tema difere: a expressão pedras fincadas/piedras hincadas tem sido a corrente na bibliografia arqueológica peninsular, enquanto que os estudiosos foráneos têm optado pela designação de chevaux-de-frise. A origem desta expressão repousa, segundo Harbinson (1968, 116), nos espigões de ferro que os Frisios dispuseram no solo, aquando do cerco de Groningen, para impedir o avanço da cavalaria inimiga; porém, Esparza Arroyo $(1980,74)$ considera preferível a primeira expressão, dado que julga haver correspondência entre os cavalos de frisa e um sistema defensivo diferente, mais moderno.

\subsection{Origem e cronologia}

A tese, já clássica, apresentada por Harbison (1968 e 1971), de uma origem centro-europeia, tem sido aceite, mais ou menos sem reservas, pela maioria dos investigadores peninsulares, de que destacamos A. Esparza Arroyo (1980, 1987 e 1995), R. Martin Valls (1971) e F. Romero Carnicero (1984 e 1991), e só mais recentemente este modelo difusionista viria a ser criticado por I. Garcés e E. Junyen (1989a) e por R Moret (1991).

Conimbriga, 39 (2000) 5-51 
De acordo com os trabalhos de Harbinson, o sistema defensivo das pedras fincadas teria tido a sua origem nas estacadas de madeira dos hillforts de Hallstatt C (século VII a.C.) da Europa Central, aparecidas no contexto dos movimentos de tracocimérios, nos quais a cavalaria tinha uma importância crescente.

Teria sido a expansão dos povos dos Campos de Umas, no seio dos quais os ginetes teriam grande protagonismo, a responsável pela chegada desta técnica defensiva ao Ocidente Europeu; porém, durante este avanço para o Sudoeste da Europa e para as Ilhas Britânicas, ter-se-ia dado a substituição da madeira pela pedra, aproveitando-se um recurso natural disponível e abundante, que apresentava, ainda, como vantagem as suas características de incombustibilidade e durabilidade. No território francês - uma escala da rota difusionista - ainda haveria a coexistência dos sistemas defensivos em madeira e em pedra, enquanto que na Península Ibérica os primeiros já estariam ausentes.

Garcés e Junyen (1989a), mais recentemente, chamaram a atenção para o facto de a coerência interna da proposta de Harbinson não ter correspondência no registo arqueológico; de facto, já Harbinson havia reparado nalgumas fraquezas da sua proposta, sobretudo por não existirem exemplos suficientes da utilização de pedras fincadas no território que separa a Meseta espanhola da Europa Central, pelo que o recurso à suposta existência, em parte deste percurso difusionista, de protótipos de madeira, mais facilmente degradáveis, tenha sido um expediente utilizado para fortalecer esta proposta. Mesmo a cronologia dos dois únicos exemplares existentes no Sul de França é problemática: por um lado, o campo de estacas de Fou de Verdun (Lavault-de-Fréloy, Nièvre), provavelmente da época cesariana, apresenta uma cronologia posterior à tradicionalmente aceite para as pedras fincadas da Meseta; por outro, as pedras fincadas de Pech Maho (Sigean, Aude) são por si só problemáticas, porquanto os autores do seu estudo têm mostrado insegurança na sua datação, ao atribuírem-nas aos séculos VI, V-IV e III a.C. (Garcés e Junyent 1989a, 44).

$\mathrm{Na}$ década de 50, Hogg (1957) propôs uma filiação hispânica para as pedras fincadas, mas a investigação posterior inviabilizou esta proposta (Garcés e Junyen 1989a, 43).

Como veremos de seguida, também as propostas cronológicas que se têm apresentado para os campos de pedras fincadas peninsulares, à excepção de Eis Vilars (Arbeca, Lleida), não são absolutas por não resultarem da evidência de contextos estratigráficos; antes, encontram- 
-se imbuídas de um pressuposto difusionista, aceitando-se que os mais orientais são mais antigos em comparação com os ocidentais e que aqui, baseando-se numa acepção evolutiva, também os sistemas defensivos são mais complexos. $\mathrm{Na}$ ausência de conhecimento do contexto estratigráfico das pedras fincadas, considera-se a organicidade das defesas e assentamentos (Esparza Arroyo 1986, 361), isto é, supõe-se que determinado sítio foi escolhido tendo em conta, entre outras coisas, as obras defensivas a realizar, segundo determinados modelos culturais e contando com os recursos humanos disponíveis, não representando as defesas um acrescento.

$\mathrm{Na}$ Meseta Norte, as muralhas e os fossos parecem ser as primeiras obras efectuadas por um grupo humano depois de ter eleito o local de assentamento de um novo povoado fortificado (Fernández-Posse e Sánchez Palencia 1997, 93), como bem patenteia La Corona de Borrenes (León); mas ainda que não seja de estranhar que a construção de um campo de pedras fincadas possa fazer parte de um mesmo projecto inicial, nada nos legitima pensar que é esta a norma adoptada em todas as novas fundações de povoados que integrem aquelas defesas, até porque são apenas complementares à própria muralha, cujo papel ultrapassa esse primário aspecto defensivo.

\subsection{Cronologia das pedras fincadas peninsulares}

As cronologias que, ao longo dos anos, têm sido propostas para a datação dos campos de pedras fincadas peninsulares são, necessariamente, aproximadas, pelo facto de não resultarem de dados estratigráficos provenientes da escavação desses espaços defensivos. Só em 1987, com a escavação realizada no povoado de Eis Vilars (Arbeca, Lleida), é que pela primeira vez se obtém uma datação segura para este engenho defensivo, a qual trará novo fôlego à discussão do tema e a necessidade de afinar propostas cronológicas anteriores.

Quando Harbinson realiza o seu já clássico trabalho sobre os castros com pedras fincadas da Península Ibérica (1968), divide-os em três grupos geograficamente distintos - mas, segundo ele, unidos pela Meseta em torno da qual formavam uma cadeia protectora - correspondendo o mais oriental aos castros da serrania de Soria, os quais, de acordo com o esquema difusionista de $\mathrm{E}$ para $\mathrm{W}$, possuiriam as datações mais antigas, por oposição aos portugueses e espanhóis fron- 
teiriços, que seriam os mais ocidentais; de permeio ficariam La Mesa de Miranda e Las Cogotas, ambos na provincia de Ávila. Este esquema difusionista gizado por Harbinson continuou subjacente às propostas cronológicas posteriores.

O recurso ao sistema defensivo das pedras fincadas está, actualmente, também comprovado em latitudes peninsulares mais meridionais, concretamente nos povoados do Passo Alto, Vila Verde de Ficalho (Soares 1986), e do Cerro del Castillo, Peñas de Aroche (Pérez Macías 1994).

Em Soria, Romero Carnicero (1991, 328-335) atribui às pedras fincadas uma cronologia que remonta, muito possivelmente, ao século VI a. C., ou, quiçá, ainda ao anterior, e supõe, contrariamente a outros autores (Lorrio 1997, 92-93), que, de modo geral, estariam em desuso na Segunda Idade do Ferro.

Os trabalhos de prospecção arqueológica desenvolvidos, nos finais dos anos 70, em $\mathrm{O}$ Courel (Lugo) permitiram identificar os povoados fortificados com pedras fincadas mais ocidentais, aos quais se atribuiu uma datação já romana (Luzón Nogué et alii 1980, 77-85). As pedras fincadas deste conjunto de povoados galegos são consideradas pelos investigadores galegos um eco tardio das da Meseta (Calo Lourido 1993,93), representando um fenómeno próprio da parte oriental da cultura castreja (Acuña 1996, 322).

Entre estes dois extremos, geográficos e cronológicos, ficariam os exemplos de Ávila, Salamanca, Zamora e Trás-os-Montes. As datações para as províncias de Ávila e Salamanca parecem ser, porém, mais modernas do que as admitidas para as outras duas (Álvarez-Sanchís 1999, 164), ainda que nelas haja também a assinalar exemplos igualmente modernos. Na Mesa de Miranda (Chamartín, Ávila) as pedras fincadas parecem estar fora de uso por altura da construção do terceiro recinto do povoado, pelo que se considera que a datação da sua muralha, centrada no século II a.C., pode funcionar como um terminus ante quem para a sua contextualização cronológica (Esparza Arroyo 1986, 359). Relativamente a Picón de la Mora e Yecla de Yeltes, ambos na provincia de Salamanca, considera-se terem a sua origem no século V a. C., embora no primeiro possa haver uma fase mais antiga, datável do Soto II, mas que não ilumina a datação precisa da muralha e pedras fincadas (idem).

Para a zona ocidental de Zamora, A. Esparza Arroyo (1986, 358-362) vinculou a maioria dos povoados fortificados com pedras fin-

Conimbriga, 39 (2000) 5-51 
cadas ao grupo Soto/Campos de Urnas Tardios, propondo uma cronologia próxima de 500 a. C., não descartando, no entanto, o surgimento de pedras fincadas em épocas posteriores, fruto do próprio desenvolvimento destas comunidades, como documenta o Castro de Lubián, na bacia do rio Tuela, que parece ter tido uma ocupação única no século III a. C.

Os resultados da campanha de escavação de 1987 no povoado de Els Vilars (Lleida, Arbeca), durante a qual se escavou parcialmente uma barreira de pedras fincadas, trouxeram novos dados para a discussão da origem e da cronologia das pedras fincadas peninsulares. A localização deste povoado no Pirenéu Catalão atribui-lhe por si só grande importância por ser o primeiro testemunho de pedras fincadas no Nordeste peninsular. Mas o impacto desta descoberta sai reforçado porquanto a integração estratigráfica das suas pedras fincadas permitiu datar da fase Vilars I (650/625-550/525 a. C.) a sua construção, bem como o seu abandono, em finais do século VI a. C., altura a partir da qual a terra as irá cobrir por completo (Garcés e Junyen 1989a).

Integrando este novo dado, Esparza Arroyo (1995, 125) reajusta a cronologia que havia proposto para os campos de pedras fincadas do Ocidente de Zamora, considerando uma passagem rápida desta técnica do vale do Ebro para o bordo oriental da Meseta e, pouco depois de 600 a. C., para Zamora, o que estaria mais de acordo com a data de radiocarbono de 253060 BP (GrN - 14794) que marca a fase inicial do Castillo de Manzanal de Abajo (Escribano 1990, 215-216), à qual, com base no pressuposto da organicidade, devem corresponder as suas defesas (muralha, fosso e pedras fincadas).

Parece claro que, à luz dos indicadores cronológicos actuais, há um desfasamento grande entre as pedras fincadas do Pirenéu Catalão e as das serranias lucenses, de, pelo menos, meio milénio. Como temos vindo a repetir, é tendência comum atribuir este desfasamento à difusão lenta e progressiva que se teria efectuado de nascente para poente. Recentemente (Moret 1991, 10-11), apontou-se outra hipótese explicativa assente no conservadorismo da cultura castreja, ou seja, a de considerar a antiguidade das pedras fincadas, aparecidas, em todo o lado, no final da I Idade do Ferro, acontecendo que as do Noroeste teriam sobrevivido às mutações da Segunda Idade do Ferro, mostrando ainda a sua vitalidade na época romana. 


\subsection{Funcionalidade}

Tem-lhes sido comummente atribuída uma função defensiva contra os ataques de cavalaria, chegando-se por vezes a invocar esta realidade para defender a existência de uma classe aristocrática ou de uma elite equestre. Nalguns lugares, a própria tradição oral parece atribuir às pedras fincadas esta mesma função: no termo de Babe (Bragança) localizam-se dois povoados providos destas defesas (n. ${ }^{\circ} 22$ e 23), as quais popularmente são interpretadas como obstáculo para travar $\mathrm{o}$ avanço de cavalos que aí partiriam as suas patas.

Alguns autores, que recentemente têm analisado em pormenor este assunto, concluem que há um desencontro entre a organização das defesas com base em campos de pedras fincadas e o papel da cavalaria (Garcés e Junyen 1989a, 45; Moret 1996, 11-13). Invoca-se que há uma proximidade habitual entre as pedras fincadas e as muralhas, e que muitas delas estão para lá de um fosso, ou entre dois fossos, os quais seriam reais obstáculos para os cavalos. Para P. Moret, a finalidade das pedras fincadas era travar a marcha da peonagem (soldados de infantaria); valoriza para isso o facto de apresentarem frequentemente uma disposição cerrada, com intervalos inferiores à amplitude do passo humano, a inexistência de campos de pedras fincadas com uma área suficientemente grande e bastante longe da muralha, mais de acordo com os objectivos de protecção contra a cavalaria, e a existência de um desfasamento entre a utilização da barreira de pedras fincadas de Eis Vilars e o desenvolvimento da criação do cavalo, que aí só ganhará importância na época ibérica (100 ou 200 anos depois do seu abandono).

Pela nossa parte, consideramos este sistema defensivo viável, quer para fazer a defesa dos povoados contra a cavalaria inimiga, quer contra peões, mas sobretudo contra a primeira, num contexto de conflito interno em que fossem comuns os assaltos por quadrilhas que esperariam, emboscadas, a melhor oportunidade para se lançarem a galope violento sobre o povoado (Esparza Arroyo 1995, 123-125).

Nos casos em que as pedras fincadas constituem o primeiro obstáculo à passagem do inimigo, mesmo antes de um fosso, elas teriam a vantagem de desorientar o cavalo e de barrar o seu avanço, já que só muito dificilmente progrediria pelo seu interior.

A existência de pedras fincadas nos espaços que separam fossos, ou entre os fossos e as muralhas, poderia ter para a cavalaria um sentido 
essencialmente dissuasor, sobretudo nos casos de fossos mais estreitos que, apesar de difícilmente transponíveis, poderiam ser encarados como tal, o que deixaria de acontecer se cavalo e cavaleiro percepcionassem do outro lado desse obstáculo um ouriçado de pedras fincadas. Teriam, porém, um efeito mais prático contra o avanço de peões, que em todo o caso teriam de rodear o(s) fosso(s).

Reforça estas atribuições funcionais o facto de, pelo menos a partir do século VII a. C., estarem criadas condições para o aproveitamento bélico do cavalo (Lucas e Rubio 1986-1987, 441 e 444). A domesticação do cavalo na Meseta deve-se ter desenvolvido, pelo menos, no decurso do II milénio a. C., permitindo o aproveitamento das qualidades específicas deste animal, nomeadamente a agilidade e a potência, e até o prestígio social que confere; ao longo do I milénio a. C., o cavalo assume alguma preponderância: a introdução de elementos metálicos, em substituição dos orgânicos, documentada, por exemplo, pelo achado de um freio de cavalo de duplo canhão no depósito do Castro de Sansueña (Zamora), datado dos séculos IX-VIII a.C. (Delibes 1980, 221-246), potenciou o desenvolvimento de atrelagens e arreios, aumentando a eficácia da cavalaria e da atrelagem e criando condições para o aparecimento da cavalaria como instrumento de guerra, levando-a a atingir um estatuto privilegiado e poderoso.

\section{Povoados fortificados com pedras fincadas em Trás-os-Montes}

Desde as primeiras décadas deste século que a bibliografia arqueológica regional dá conta da existência de povoados fortificados com campos de pedras fincadas (Alves 1931, 38-39 e 1934, 71, 105, 107, 149, 180 e 513; Lopo 1987, 19, 62-63, 129-130 e 159), tal como acontecia na arqueologia espanhola (Gómez Moreno 1904, 148; Taracena 1929, 7-14).

O primeiro, e único, trabalho de conjunto sobre esta particularidade do sistema defensivo dos povoados fortificados transmontanos é da autoria de P. Harbinson (1967-1968, 385-389), sendo, na realidade, uma adaptação do seu artigo, do mesmo ano, publicado nos Madrider Mitteilungen, o qual temos vindo a citar. Neste artigo dedicado exclusivamente aos castros com pedras fincadas de Trás-os-Montes, publicado nos Trabalhos de Antropologia e Etnologia, considerou que

Conimbriga, 39 (2000) 5-51 
estes povoados, tal como os da Meseta de León e Castilla, se integrariam na denominada "Cultura de los Verracos" e que a sua origem, por confronto com os exemplos espanhóis, radicaria nos últimos quatro séculos a. C., ainda que alguns, como o de Carvalhelhos, continuassem ocupados até ao período romano.

A investigação da proto-história transmontana não receberá grandes contributos até aos inicios dos anos 90, altura em que Francisco Sande Lemos (1993) apresenta, no âmbito da sua tese de doutoramento, um trabalho, sem precedentes, sobre o povoamento proto-histórico e romano de Trás-os-Montes Oriental. No entanto, este trabalho, que faz a síntese dos conhecimentos acumulados pelos estudiosos locais desde finais do século passado, não dá o realce merecido à discussão da problemática dos campos de pedras fincadas. Ainda assim, conclui pela não existência de um modelo de povoados fortificados com pedras fincadas (Lemos 1993, Ia, 194) e admite como hipótese que este sistema defensivo se tenha generalizado em povoados de cronologia recuada, atribuível à I Idade do Ferro, implantados em contrafortes montanhosos e cumeadas com óptimas condições geo-estratégicas e amplo domínio visual - o seu tipo C (idem, 204-206), no qual se integram o Monte de Santa Comba de Ousilhão (n. $\left.{ }^{\circ} 13\right)$ e o Castelo de Alimonde (n. $\left.{ }^{\circ} 14\right)$.

Conhecem-se no território transmontano 30 povoados fortificados cujos sistemas defensivos incluem pedras fincadas ${ }^{1}$ (Fig. 1), mas é 1

${ }^{1} \mathrm{O}$ povoado fortificado designado de Castelo da Cidadelha que a bibliografia (Alves 1931; Montalvão 1971; Esparza Arroyo 1980, 76, n. ${ }^{\circ}$ 21; Luzón Nogué et alii 1980, 81 e 82, n. ${ }^{\circ}$; Tranoy 1981, 86; Martins 1984, n. ${ }^{\circ}$ 36; Silva 1986, 92, n. ${ }^{\circ}$ 548) localiza no termo de Segirei (S. Vicente da Raia, Chaves) integra-se em território galego, no concelho de Vilardevós (Taboada Chivite 1955, 336; Rodríguez Colmenero 1977, 113), junto à linha de fronteira com Portugal (CMP 1:25.000 n. ${ }^{\circ} 22$; Coord. Gauss: M-276,3 / P-546,0; Alt.: 680 m).

Ocupa o topo de um cabeço com razoáveis condições naturais de defesa situado entre os regatos da Cidadelha e do Pontón. É envolvido por um circuito de muralha que se vai adossando aos afloramentos rochosos emergentes e define um recinto pouco extenso, com aproximadamente $100 \times 50 \mathrm{~m}$ nos eixos maiores. A muralha atinge os $3 \mathrm{~m}$ de largura e parece construída com duplo paramento de grandes blocos pétreos. A defesa do sector noroeste do povoado é reforçada por um pequeno torreão associado à muralha e por um campo de pedras fincadas que ocupa cerca de $30 \mathrm{~m}$ imediatamente em frente da muralha, entre a bancada rochosa que aí se levanta (orientada no sentido noroeste-sudeste) e a própria vertente do esporão, num espaço de aproximadamente $20 \mathrm{~m}$. As pedras fincadas dispõem-se de forma cerrada, praticamente encostadas umas

Conimbriga, 39 (2000) 5-51 
provável que este engenho defensivo pudesse ter sido bastante mais comum, a avahar pelo número de novas descobertas que se vão sucedendo, quer no território nacional, quer em Espanha, e pela possibilidade de muitos deles se encontrarem encobertos, pela acção dos fenómenos post-deposicionais, ou desmantelados, sobretudo, devido aos labores agrícolas e ao aproveitamento das pedras para a construção civil; infelizmente, os povoados fortificados proto-históricos continuam a ser "pedreiras do povo", facto que o Abade de Baçal (Alves 1934, 107) já realçava, a propósito do estado de conservação do Castelo dos Mouros de Algosinho (n. $\left.{ }^{\circ} 25\right)$, queixando-se de que as pedras têm sido levadas à formiga para tapagem de propriedades particulares.

A maioria destes povoados (19) localiza-se no Nordeste transmontano, entre os rios Douro e Tuela, mas a sua distribuição avança mais para poente, alcançando o território entre o Tâmega e Cávado superiores, administrativamente integrado nos concelhos de Chaves e Boticas. Os exemplos mais meridionais surgem, no território mais oriental, em Lagoaça (Freixo de Espada-à-Cinta) e Parada (Alfândega da Fé) e, mais a ocidente, em Vale de Égua (Murça), Sabrosa e Alijó.

Ocupam, sobretudo, relevos em esporão ou arribas sobranceiros a cursos de água mais ou menos imponentes, mas também cabeços destacados na paisagem. Há ainda exemplos singulares de implantação no rebordo de um planalto e num "castelo rochoso". A presença de pedras fincadas nestes povoados apenas os diferencia por isso mesmo, não parecendo ter qualquer significado especial, para além do reforço da defesa em sectores mais vulneráveis, de maneira geral em locais de fraca pendente por onde seria fácil o acesso de cavalaria ou peonagem.

Em alguns povoados foi criada mais de uma área com este engenho defensivo. O Castro de Carvalhelhos ( $\mathrm{n}^{\circ}$ 1) e Cidadelhe de Parada de Infanções (n..$^{\circ}$ 16) são disso bons exemplos: no primeiro, no seu sector ocidental, foi levantado um campo de pedras fincadas antes do fosso externo e foi coroado com estas pedras o topo de pelo menos um talude de separação dos fossos; no segundo, regista-se, no sector sudeste, um conjunto de pedras fincadas exterior ao fosso e um outro, no lado noroeste, entre o fosso e a muralha. Esta combinação de fórmulas diferentes de posicionamento das pedras fincadas num mesmo

às outras, e apresentam morfologias e dimensões muito variadas devido, sobretudo, às características da pedra utilizada (xisto quartzoso), atingindo, acima do solo, alturas médias que oscilam entre os 0,40 e os $0,80 \mathrm{~m}$, embora algumas alcancem $1 \mathrm{~m}$. Rodríguez Colmenero refere a existência de construções circulares e de cerâmica romana que nós não detectámos. 
povoado revela seguramente que não há na escolha de diferentes fórmulas de ordenação das defesas de um povoado qualquer significado profundo, para além do seu sentido defensivo.

Habitualmente, as pedras fincadas constituem a defesa mais externa destes povoados. Nesta situação, as áreas de pedras fincadas podem anteceder um fosso ou estar em frente às próprias muralhas.

No Crasto de Nogueira (n. ${ }^{\circ}$ 2), no Castro da Curalha (n. ${ }^{\circ}$ 7), no Castelo de Alimonde (n. ${ }^{\circ}$ 14) e no Cabeço da Coroa (n. $\left.{ }^{\circ} 19\right)$, todos eles implantados no alto de cabeços, no Castro da Sapeira (n. ${ }^{\circ} 22$, foto 5) e na Castragosa (n. ${ }^{\circ} 23$ ), ambos no termo de Babe e implantados em relevos em esporão, as pedras fincadas antecedem a muralha, tal como no Castrilhouço de Vale de Águia (n. ${ }^{\circ} 29$ ) ou na Cigaduenha de Picote (n. ${ }^{\circ} 28$, foto 6 ), onde a única zona de acesso aos povoados, sobranceiros ao rio Douro, estava barrada por um campo de pedras fincadas secundado, no primeiro caso, por uma muralha e um torreão e, no segundo, apenas por uma muralha.

O mais frequente, porém, é os estrepes estarem associados a fossos. O valor defensivo destes fossos é indiscutível, mas a sua presença é também, em muitos casos, sinónimo de fonte de matéria-prima utilizável na construção do restante aparato defensivo, e até doméstico, dos povoados; os materiais retirados da sua escavação encontram bastante utilidade na hora de se construírem parapeitos, muralhas e habitações e, evidentemente, se levantarem barreiras de pedras fincadas. Nos povoados implantados em esporões ou arribas que possuem áreas de pedras fincadas a anteceder um ou mais fossos, constituindo a defesa mais avançada do povoado, o mais comum é a sua localização coincidir com o sector de mais fácil acesso ao povoado, como se verifica no Castro de Carvalhelhos (n. ${ }^{\circ}$ 1, foto 1), no Muro de Pastoría (n. ${ }^{\circ}$ 6), na Murada de Lama de Ouriço (n. $\left.{ }^{\circ} 10\right)$, na Terronha de Vimioso (n. $\left.{ }^{\circ} 26\right)$, no Castro de S. Martinho de Angueira (n. ${ }^{\circ}$ 27), no Castelo dos Mouros de Algosinho (n. $\left.{ }^{\circ} 25\right)$ e no de Vilarinho dos Galegos (n. $\left.{ }^{\circ} 24\right)$ e no Castelo Velho de Bruçó (n. ${ }^{\circ}$ 21). À excepção dos dois primeiros povoados citados, nos restantes esta formação defensiva era reforçada por um torreão, pegado à estrutura amuralhada, que se levantaria vigilante por trás do fosso. Contudo, encontramos também outras soluções. Na Casa da Mina de Vilar de Perdizes (n. ${ }^{\circ}$ ), a zona de mais fácil acesso ao povoado é defendida por um torreão unido a duas linhas de muralha e por um duplo fosso, enquanto que as pedras fincadas estão colocadas noutros sectores do povoado também vulneráveis pela mediocridade 
das condições naturais de defesa. Nos povoados com outro tipo de implantação (cabeços, cumeadas...) a opção foi também o reforçar das defesas onde o acesso é mais favorável, como se verifica no Monte de Santa Comba de Ousilhão (n. ${ }^{\circ}$ 13, foto 4 ) ou em Cidadelhe de Parada de Infanções (n. $\left.{ }^{\circ} 16\right)$.

Pedras fincadas colocadas entre um fosso e a muralha do povoado surgem no Castelo de Calvelhe (n. ${ }^{\circ}$ 20) e em Cidadelhe de Parada de Infanções (n. $\left.{ }^{\circ} 16\right)$, enquanto que as cristas de pedras fincadas a coroar taludes de separação de fossos apenas têm existência clara no Castro de Carvalhelhos (n. $\left.{ }^{\circ} 1\right)$.

Referência especial merece o Castelo dos Mouros de Vale de Égua (n. ${ }^{\circ}$ 9, foto 2) pela situação do seu campo de pedras fincadas relativamente às restantes defesas. Neste povoado, utilizaram-se as pedras fincadas associadas, de forma original, ao mais externo de dois terraplenos que envolvem o seu sector norte; as pedras, com alturas variáveis entre os 0,15 e os $0,40 \mathrm{~m}$, concentram-se encostadas ao limite exterior do terrapleno e estrategicamente voltadas para o colo de acesso ao povoado, numa extensão de $20 \mathrm{~m}$ de comprimento e 6 a $7 \mathrm{~m}$ de largura, mas que poderia ter sido mais vasta.

Quando na área a dotar de pedras fincadas existem pequenos afloramentos, graníticos ou xistosos, como acontece por exemplo na Casa da Mina de Vilar de Perdizes (n. ${ }^{\circ}$ 3), no Castro da Curalha (n. ${ }^{\circ}$ 7), na Murada de Lama de Ouriço (n. ${ }^{\circ}$ 10), na Murada de Fiães (n. ${ }^{\circ}$ 11, foto 3) ou no Monte de Santa Comba de Ousilhão (n. ${ }^{\circ} 13$ ), é comum as pedras fincadas combinarem-se com esses obstáculos naturais, rodeando-os e preenchendo os espaços livres entre eles, mesmo que diminutos. No caso específico do povoado de Fiães, onde esta complementaridade está muito bem conseguida, verifica-se que a eficácia desta associação é ainda reforçada pelo facto de o fosso, cortado na rocha, interposto entre as pedras fincadas e a muralha, aparecer dissimulado por esses mesmos afloramentos.

A nossa posição relativamente à possibilidade de definir cronologicamente o uso de pedras fincadas em Trás-os-Montes reveste-se de algum pessimismo, residente no facto de não dispormos de dados de escavação para qualquer dos campos de pedras fincadas e, agravando o panorama, na escassez de indicadores cronológicos para a ocupação dos próprios habitats. Contudo, parece-nos razoável tentar esboçar uma cronologia ampla, à escala de uma fase cultural, como sugeriu R Moret $(1996,8)$, com base nos sítios que oferecem alguns dados cronológicos, 
embora correndo sempre o risco de as pedras fincadas que pretendemos estudar poderem ter correspondência com uma fase da qual não se conhece qualquer vestígio material, por nunca ter sido detectado em prospecções ou mesmo em sondagens.

Os quatro povoados com pedras fincadas que foram objecto de escavação localizam-se todos na franja mais ocidental da área de dispersão deste sistema defensivo, mas nem por isso essa realidade é vantajosa na hora de definir cronologias: os contextos cronológicos do Castro de Carvalhelhos (n. $\left.{ }^{\circ} 1\right)$ e das suas barreiras de pedras fincadas não estão claramente definidos, apesar de este povoado apresentar uma larga área intervencionada, ao longo de três décadas: se por um lado estão referenciadas cerâmicas de tipologia castreja, por outro há todo um conjunto de espólio cerâmico, metálico e numismático que documenta uma ocupação efectiva do local no período alto-imperial (Santos Júnior 1984c); as sondagens efectuadas no Muro da Pastoría (n. ${ }^{\circ}$ 6), apesar de limitadas, indicaram uma cronologia recente, do século I a.C, para os níveis de ocupação escavados, embora fique em aberto a possibilidade de uma fundação anterior (Soeiro 1986); a análise dos dados referentes ao Castro da Curalha (n. $\left.{ }^{\circ} 7\right)$ deixa-nos alguma perplexidade pelo facto de os resultados conhecidos apontarem para uma ocupação bastante tardia, mormente do Baixo Império e da Alta Idade Média (Amaral 1993, 39-40), pouco consentânea com o uso do sistema defensivo de pedras fincadas. A integração do outro povoado escavado, o de Sabrosa (n. ${ }^{\circ}$ ), neste rol de povoados fortificados com pedras fincadas é duvidosa, pois ainda que seja certa a sua ocupação na Idade do Ferro e no período romano, a existência de pedras fincadas é apenas suspeitada por um escrito jornalístico, não sendo confirmada pela restante bibliografia, nem tão-pouco pela visita que aí efectuámos.

Apesar da exiguidade dos dados cronológicos disponíveis e da imperiosidade de (re)avaliação do espólio arqueológico e das estratigrafías dos povoados fortificados de Carvalhelhos, Curalha e Sabrosa, fica-nos a impressão de que a maioria dos povoados com pedras fincadas mais ocidentais, localizados a poente dos rios Rabaçal e Tuela, estavam em plena ocupação, pelo menos, no câmbio de Era, podendo o seu sistema defensivo ter estado em funcionamento ou mesmo ter sido construído nessa época, como parece acontecer com o Castelo dos Mouros de Vale de Égua (n. ${ }^{\circ}$ 9), classificado como povoado mineiro fortificado de fundação romana (Lemos 1996, 149), tal como os exemplos de O Caurel (Lugo).

Conimbriga, 39 (2000) 5-51 
Para muitos dos povoados da parte oriental de Trás-os-Montes não dispomos de qualquer indicador cronológico, sendo, mal-grado, os povoados com deficientes condições de conservação que nos facultam um maior número de dados com valor cronológico.

No Monte de Santa Comba de Ousilhão (n. ${ }^{\circ}$ 13), Sande Lemos (1993, lia, 433-434), na sequência de destruições provocadas pela instalação de urna antena retransmissora, recolheu cerâmicas que apontam para uma cronologia que recua à I Idade do Ferro, ao horizonte cultural de Soto de Medinilla, e, com base nessas evidências e na estrutura do próprio povoado, sugere, como hipótese a confirmar, que tenha sido com os povoados correspondentes ao seu tipo $\mathrm{C}$, que se generalizou em Trás-os-Montes Oriental o sistema de pedras fincadas.

Alguns dos materiais cerâmicos recolhidos no Castrilhouço de Vale de Águia (n. ${ }^{\circ}$ 29) (Sanches 1992, 55, 153, est. XXVI e XXVII; Lemos 1993, III, est. LXXVI, 3, 6, 7, 8) encontram paralelos nas cerâmicas de Zamora ocidental, tal como acontece com os fragmentos recolhidos no Castro de S. Martinho de Angueira (n. ${ }^{\circ}$ 27), cujas cerámicas publicadas por Esparza Arroyo (1986, 143-145) são paralelizáveis com as do Castro de Sejas de Aliste (Zamora), e integráveis no horizonte cultural de Soto de Medinilla. Do conjunto cerâmico associado a este último povoado destaca-se um pequeno fragmento cerámico com pintura avermelhada que, segundo recentes propostas cronológicas para as cerámicas pintadas da Meseta (Romero Carnicero 1991, 284-292 e 499), deverá ser datado dos séculos VI-V a. C.

A manter-se o cenário, indiciado pelos conjuntos cerâmicos recolhidos no Monte de Santa Comba de Ousilhão (n. ${ }^{\circ}$ 13), no Castrilhouço de Vale de Águia (n. ${ }^{\circ}$ 29) e no Castro de S. Martinho de Angueira (n. ${ }^{\circ}$ 27), de integração do Nordeste transmontano no horizonte cultural do Soto de Medinilha, é possível pensar no aparecimento deste sistema defensivo na Idade do Ferro, provavelmente no século VI a. C., data fundacional atribuida ao Castillo de Manzanal de Abajo (Zamora), que para Escribano Velasco $(1990,215-216)$ representa a projecção para o Ocidente da cultura do Soto e com o qual o Monte de Santa Comba tem evidentes paralelos quanto aos sistemas defensivos e aos próprios materiais cerâmicos (Lemos, 1993, Ia, 180).

Da cronologia dos povoados com pedras fincadas mais ocidentais, integrados na parte mais oriental de uma realidade cultural diferente, no seio da nebulosa cultura castreja, onde se enquadram os povos que as fontes epigráficas e clássicas apresentam como organizados em 
castella e que seguramente já na Idade do Ferro teriam uma organização social distinta, temos, tão-só, um terminus ante quem, o Alto Império romano. Teremos, porém, que pensar que a presença deste sistema defensivo em povoados de fundação romana se deve a uma tradição anterior, que nessa altura se mantinha viva, mas que por ora não sabemos quando, nem de que forma, se implantou nessas paragens.

\section{Inventário dos povoados fortificados transmontanos com pedras fincadas}

Os povoados apresentam-se ordenados, de acordo com a sua longitude, de Ocidente para Oriente. Para cada povoado pretendeu-se efectuar uma síntese da informação disponível respondendo a um conjunto de itens principais: designação toponímica, integração administrativa, descrição sumária (tipo de assentamento, integração na paisagem, arquitectura defensiva, organização interna, espólio) e bibliografia referentes a cada um deles.

A descrição que efectuámos destes povoados fortificados baseia-se, sobretudo, nos dados disponíveis na bibliografia. Das nossas próprias observações resultou o enriquecimento das descrições apresentadas para os n.os $1,3,5,7,9,10,11,13,16,17,22,23,28$ e 29.1

\section{Couto dos Mouros/Crasto/Castro de Carvalhelhos, Beça, Boticas}

(CMP 1:25.000 n. ${ }^{\circ} 46$; Coord. Gauss: M-233.3/P-525.3; Alt.: 860m)

Localiza-se num relevo em esporão limitado pelo curso do ribeiro do Castro, afluente do rio Beça, para o qual se voltam vertentes algo íngremes, enquanto que a topografia do lado sudoeste é mais suave, esboçando apenas uma ligeira depressão que individualiza este esporão na sua união com a ladeira a que se une.

O povoado foi objecto de trabalhos arqueológicos entre 1952 e 1983, orientados por Joaquim dos Santos Júnior, a partir dos quais se produziram numerosos títulos.

Uma primeira linha de muralha, incompleta, forma um recinto de planta semicircular, cujos eixos máximos medem $51 \mathrm{~m}(\mathrm{~N}-\mathrm{S})$ e 42,5 m (E-O), com um entrada a sudoeste, a partir de um recinto externo; esta muralha tem uma largura média de 2,5 a $3 \mathrm{~m}$ e, de acordo com Harbinson, tem do lado nascente um traçado curvilíneo, ausente dos lados sudoeste, sudeste e este, onde o seu

Conimbriga, 39 (2000) 5-51 
traçado é feito por tramos rectos formando pequenos ângulos entre eles. Pelo poente, encosta abaixo, existe uma outra linha de muralha que tem na sua extremidade setentrional uma pequena projecção para o interior, ainda não claramente explicada, que se interrompe em frente de um afloramento rochoso voltado a noroeste, a norte e nordeste, na base do esporão e junto ao curso de água, existe uma terceira linha de muralha, com uma configuração rectilínea e uma espessura inferior aos 2,5 ou $3 \mathrm{~m}$ que se documentam, em média, nas restantes, conservada em cerca de $100 \mathrm{~m}$.

A muralha superior é construída com duplo paramento, sendo o externo executado em pedra de granito, de pequenas dimensões, em que apenas a face externa é afeiçoada, formando um opus incertum, e o interno em pedra de xisto. Noutros panos de muralha, como por exemplo no lado poente, apenas é utilizado o xisto. As linhas de muralha do recinto superior e do lado oeste dispõem de rampas de acesso obtidas por um alargamento da sua face interna em cerca de $0,50 \mathrm{~m}$, contabilizando-se 10 ou 11 rampas na primeira e 5 na segunda.

A estrutura defensiva deste povoado é complementada por outras defesas: no lado menos defensável existem três fossos, cujas dimensões oscilam ente os 5 e os $8 \mathrm{~m}$ de profundidade e os 6 e os $8 \mathrm{~m}$ de largura, que se estendem para os lados este e oeste, à excepção do central, que se limita ao lado sudoeste, reforçados por conjuntos de pedras fincadas. A maior extensão de pedras fincadas ocupa uma área de cerca de 40 a $50 \mathrm{~m}$ de comprimento e 8 a $10 \mathrm{~m}$ de largura, bordejando parcialmente o fosso externo entre o noroeste e o sudoeste, embora elas tenham também sido encontradas no talude que separa os dois fossos do lado poente e pudessem ter coberto, originalmente, todos os taludes separadores dos fossos, nomeadamente no lado sudoeste. As pedras fincadas conservadas, com uma disposição muito densa, elevam-se acima do solo numa altura média que oscila entre os 0,25 e os $0,30 \mathrm{~m}$, ainda que algumas possam ultrapassar os $0,50 \mathrm{~m}$. Não foram produzidos argumentos suficientemente seguros, baseados em evidências estratigráficas, para esclarecer a existência ou não de duas fases construtivas do povoado e, pese embora as conjecturas de Harbinson, apenas parece mais ou menos evidente, embora não irrefutável, que as pedras fincadas têm uma história paralela à dos dois fossos maiores, para os quais também não se obteve qualquer cronologia.

No interior do recinto superior foram individualizadas quatro casas de planta circular e três de planta rectangular, enquanto que no seu exterior, do lado nascente, se identificaram duas de planta circular, uma com vestíbulo, e outras duas rectangulares, mas em nenhum dos recintos parece possível perceber qualquer lógica de organização interna do espaço.

O espólio recolhido ao longo de três décadas reveste-se de alguma pobreza.. Em 1965, foi encontrado um depósito com $200 \mathrm{Kg}$ de cassiteri te, associado a alguns fragmentos cerâmicos, cossoiros, pregos em ferro e outros 
objectos metálicos, entre os quais estariam, aparentemente, arcos de fíbulas; no recinto superior e no recinto externo apareceu grande quantidade de escorias, o que parece documentar a prática da metalurgia do bronze no povoado. Os fragmentos cerâmicos, recolhidos durante os trabalhos de escavação, enquadram-se ñas tipologías castrejas; são, de forma geral, lisos e as suas pastas têm frequentemente grande quantidade de micas. Do espolio metálico sobressai uma fíbula anular romana (Flower B1) e urna fíbula do tipo Aucissa (Cam 17c), com cronologias já imperiais, uma fivela em bronze e um pendente no mesmo metal. Foi igualmente exumada uma folha de lança em ferro, bem como outros fragmentos de ferro. Associam-se, ainda, a este povoado um disco em prata a que Santos Júnior atribui valor monetário e vários numismas de que apenas surgem individualizados dois asses de Tibério e um de Augusto e um denário, também augustano. Acrescentam-se a este rol duas singulares contas em pasta vítrea e uma pedra de anel.

BIBLIOGRAFIA: Santos Júnior 1957; 1959-60; 1963; 1964; 1966; 1971; 1973; 1975a; 1977; 1978; 1980; 1981; 1982; 1983a; 1984a e 1984c; Harbinson 1968, 116-120; Esparza Arroyo 1980, 76 (n. 14); Luzon Nogué et alii 1980, 81 e 82 (n. $\left.{ }^{\circ} 8\right)$; Tranoy 1981, 86; Martins 1984, n. ${ }^{\circ} 15$; Ponte 1984, 173 (n. ${ }^{\circ} 73$ ); Silva 1986, 89 (n. $\left.{ }^{\circ} 483\right)$; Centeno 1987, 113 (n. $\left.{ }^{\circ} 37\right)$.

\section{Crasto, Nogueira, Bobadela, Boticas}

(CMP 1:25.000 n. ${ }^{\circ} 33$; Coord. Gauss: M-241.5/P-530.7; Alt.: 900m)

$\mathrm{O}$ povoado implanta-se num cabeço de configuração cónica, situado a noroeste da aldeia de Nogueira.

A sua estrutura defensiva é constituída por uma linha de muralha, mal conservada, que atingiria os $3 \mathrm{~m}$ de largura, e por um campo de pedras fincadas que se estenderia, do lado poente, 8 a $10 \mathrm{~m}$ em frente da muralha (sentido E-W). Dois troços de derrubes da muralha conservam-se no lado ocidental do povoado: um entre o sudoeste e o oeste, numa extensão de $60 \mathrm{~m}$, a meio do qual restam indícios da existência de uma rampa de acesso à muralha, e outro de $\mathrm{W}$ para norte, configurando um S, numa extensão de $45 \mathrm{~m}$. O restante perímetro nordeste, este e sudoeste - aproveita as condições naturais de defesa proporcionadas pelos afloramentos sucessivos que por aí se perfilam. A bibliografia refere, ainda, a hipotética existência de um segundo recinto amuralhado, do lado sul.

O espólio deste povoado resume-se a fragmentos cerâmicos e a uma fíbula do tipo Aucissa (Cam. 17 c) com uma cronologia já romana, do século Id.C.

BIBLIOGRAFIA: Kalb 1980, (n. ${ }^{\circ}$ 30); Ponte 1984, 134 (n. ${ }^{\circ}$ 51); Martins 1984, (n. ${ }^{\circ}$ ); Miranda Júnior et alii 1985, 13-19; Silva, 1986, 90 (n. ${ }^{\circ} 488$ ).

Conimbriga, 39 (2000) 5-51 


\section{Casa da Mina/Castro da Mina, S. Miguel (Vilar de Perdizes), Montalegre}

(CMP 1:25.000 n. ${ }^{\circ}$ 20; Coord. Gauss: M-243.6/P-542.4; Alt.: 730m)

Povoado de grandes dimensões e configuração subcircular, implantado num esporão com medíocres condições naturais de defesa, mas com considerável domínio visual sobre o vale da ribeira da Assureira.

A estrutura defensiva do povoado é composta por três linhas de muralha e um torreão, três fossos e uma extensa barreira de pedras fincadas.

Ao torreão, voltado a noroeste, estão unidas as muralhas superior e intermédia. A superior parte do lado norte do torreão tomando a direcção nascente para em seguida passar a descrever um traçado curvilíneo que a leva a adossar-se novamente ao torreão. A intermédia une à parte exterior do torreão e segue inicialmente na direcção norte, para logo de seguida se orientar para nascente até o seu traçado inflectir abruptamente, em ângulo aberto $\left(100^{\circ}\right)$, para sul, aproximando-se progressivamente da linha de muralha superior, até passar a seguir quase paralela a esta, separada por escasso espaço que se vai reduzindo no lado poente, até quase se juntar, acabando por se ligar também ao torreão (a ponto de por vezes se misturarem e confundirem os respectivos derrubes); esta segunda muralha acaba por envolver por completo a primeira e criar, a uma cota inferior, um segundo recinto, particularmente amplo no lado setentrional do povoado. Uma terceira linha de muralha, acoplada à intermédia, define outro recinto, de configuração esguia, no sector nascente; esta linha de fortificação levanta-se a partir do ângulo descrito pela muralha intermédia quando toma o rumo sul, e toma esta mesma direcção até que imediatamente antes do fosso do sector sudeste encurva para encontrar novamente aquela muralha.

As muralhas são de alvenaria seca de granito, com aproximadamente 2,50 m de largura, apresentando duplo paramento de aparelho regular de blocos rectangulares, dispostos em fiadas, embora em alguns troços, sobretudo na muralha inferior, se utilize um aparelho irregular de lajes sobrepostas a seco. $\mathrm{Na}$ muralha intermédia distingue-se uma porta (orientada para nordeste), conseguida pela interrupção da própria muralha e marcada com grandes lajes graníticas, que comunica com o recinto inferior.

Um fosso profundo envolve o povoado na maior parte do seu perímetro: é visível em parte do sector nascente do povoado e acompanha a linha de muralha exterior, sem interrupção, a setentrião e a poente. $\mathrm{Na}$ continuação deste fosso é visível um outro que envolve o povoado no seu sector sudeste, a toda a largura do remate do esporão em que se encontra implantado o povoado; os dois fossos estão separados por escassos metros no sector sul do povoado.

No sector noroeste, pela sua maior acessibilidade e vulnerabilidade, a estrutura defensiva é reforçada, em frente ao torreão, com um outro fosso, exterior ao já descrito.

Conimbriga, 39 (2000) 5-51 
Uma extensissima barreira de pedras fincadas com cerca de $30 \mathrm{~m}$ de largura, exterior ao fosso interno e ao fosso do sector sudeste, completa a defesa do povoado ao longo de aproximadamente duas centenas de metros; cobre, a praticamente toda a largura, o remate do esporão e prolonga-se pelo sul e poente até ao sector noroeste, detendo-se ao aproximar-se da área protegida por duplo fosso. As pedras conservam alturas acima do solo que oscilam entre os 0,10 e os $0,40 \mathrm{~m}$. O empenho defensivo colocado nestes sectores justifica-se pela ausência de boas condições naturais de defesa: apesar de rodeados pela ribeira da Assureira podem, em alguns pontos, ser alcançados, a vau, a partir da outra margem da ribeira e facilmente atravessados devido ao seu pendor suave.

O espólio associado a este povoado cinge-se a um fragmento de cerâmica de fabrico manual, atribuível à Idade do Ferro, recolhido à superfície.

BIBLIOGRAFIA: Costa 1968, 43; Lourenço Fontes 1978, 16; Esparza Arroyo 1980, 76 (n. 22); Luzon Nogué et alii 1980, 81 e 82 (n. $\left.{ }^{\circ} 29\right)$; Tranoy 1981, 88; Silva 1986, 89 (n. ${ }^{\circ} 460$ ); Fontes 1992.

\section{Muro/Cunhas, Seara Velha, Calvão, Chaves}

(CMP 1:25.000 n. ${ }^{\circ} 33$; Coord. Gauss: M-245.9/P-533.3; Alt.: 709m)

O povoado implanta-se no topo de um remate de esporão, no tramo superior da bacia da ribeira de Calvão, entre a ribeira de Cunhas e uma linha de água que a ela aflui.

O sistema defensivo do povoado é composto por duas linhas de muralha, separadas cerca de $30 \mathrm{~m}$ uma da outra, formando um recinto subcircular com $120 \mathrm{~m}$ de diâmetro máximo; ambas apresentam uma largura de aproximadamente $3 \mathrm{~m}$ e uma construção, em alguns lanços, em paramento duplo, sendo o externo formado por blocos de granito rectangulares, bem aparelhados e assentes a seco. Do lado sudoeste foram aproveitados os afloramentos graníticos para adossar as muralhas. Do nascente há, segundo P. Amaral, indícios de uma rampa de acesso na face interna da muralha externa.

Do lado norte-nordeste, o mais vulnerável pela rareza dos afloramentos, o sistema defensivo é reforçado por uma área de pedras fincadas de cerca de $500 \mathrm{~m}^{2}$.

Miranda Júnior et alii detectaram indícios de duas construções, de planta possivelmente circular, no lado norte da plataforma limitada pelas duas linhas defensivas.

Associam-se ao povoado fragmentos de cerâmica proto-histórica, alguns dos quais de fabrico manual, um cossoiro e uma escória de ferro.

BIBLIOGRAFIA: Azevedo 1896, 257 (n. 42); Montalvão 1971, 94;

Conimbriga, 39 (2000) 5-51 
Martins 1980a; 1984 (n. 38); 1985, 24 (n. $\left.{ }^{\circ} 33\right)$; Miranda Júnior et alii 1985, 19-28; Silva 1986, 91 (n. ${ }^{\circ}$ 517); Santos Júnior 1988-89; Amaral 1993, 73-74 (n. $\left.{ }^{\circ} 120 \mathrm{~B}\right)$.

\section{Castro/Cristêlo/Castelo dos Mouros/Castelo da Sancha, Sabrosa, Sabrosa}

(CMP 1:25.000 n. ${ }^{\circ}$ 155; Coord. Gauss: M-247,0/P-478,9; Alt.: 665 m)

O povoado está implantado num cabeço da vertente oriental da serra do Criveiro, sobranceiro ao rio Pinhão.

Foi objecto de trabalhos arqueológicos entre 1967 e 1971, e entre 1980 e 1984, sob a direcção de Santos Júnior e Carlos Ervedosa.

A planta do povoado apresenta uma configuração trapezoidal que the é conferida pela linha de muralha externa, a qual contém as outras duas. A muralha externa, com uma espessura média de 3 a $4 \mathrm{~m}$, apresenta-se em grandes tramos mais ou menos rectilíneos, articulados por ângulos abertos, a norte e oeste, que conformam os lados sul, sudoeste, noroeste e este do povoado, sem que se vislumbre qualquer porta; do lado nascente, o circuito de muralha, aparentemente, interrompe-se pela existência de condições naturais de defesa proporcionadas pelas escarpas e afloramentos. A sua construção foi feita com duplo paramento de blocos de granito aparelhados e miolo de pedra mais miúda, sendo constatável em alguns tramos, nos lados norte e nascente, um paramento externo de construção bem cuidada com silhares rectangulares, talhados em cunha, sobrepostos em linhas horizontais. No interior desta linha de muralha, outras duas retalham o espaço. Junto do ângulo noroeste, no ponto mais elevado do povoado, há uma linha de muralha, em arco, com $60 \mathrm{~m}$ de extensão, construída igualmente com paramento duplo, que se adossa à muralha externa; define um recinto semi-elíptico, ao qual se acede por três portas, voltadas a sul, este e nordeste, no qual foram identificadas 5 casas, algumas adossadas à muralha, um torreão e algumas rampas de acesso à muralha externa. Envolvendo este reduto, um outro arco de muralha, não adossado a qualquer uma das duas linhas de muralha já descritas, impõe-se como defesa artificial pelo nascente, onde a muralha externa está ausente, para, de nordeste a noroeste, se internar no espaço amuralhado pela linha externa; esta linha defensiva dispõe de uma entrada, voltada a nascente ainda protegida pelo tramo nordeste da muralha externa, denunciada por uma interrupção do pano de muralha que se encurva para o lado interno. A defesa do povoado é reforçada por dois extensos fossos que, nos lados menos defensáveis (norte e poente) antecedem a muralha externa. Numa notícia, publicada no Jornal de Notícias, em 6-8-1968, referente à estada de Santos Júnior no Castro de Sabrosa durante a campanha desse ano, é levantada a hipótese da existência de uma "crista de pedras fincadas" associada ao duplo fosso, porém, dado que 
tal hipótese não voltou a ser comentada, permanece a dúvida quanto a ter ou não existido esta área de pedras fincadas. A nossa visita ao local foi inconclusiva, sobretudo devido a algumas perturbações que afectaram essa área.

O espólio recolhido é constituído por fragmentos de cerâmica comum, lisos e decorados, com uma cronologia que oscila entre a Idade do Ferro e a Idade Média, bolas de funda em quartzo leitoso, um machado em ferro, fíbulas, moedas romanas, entre as quais um asse de Tibério, e três epígrafes romanas, duas funerárias e uma votiva, consagrada a Júpiter.

BIBLIOGRAFIA: Ervedosa 1967-68; 1981; 1982; 1983; 1984; 1985a e 1985b; Santos Júnior 1969; 1975c; Jornal de Notícias, de 06-08-1968; Esparza Arroyo 1980, 76 (n. ${ }^{\circ}$ 20); Silva, 1986, 94 (n. ${ }^{\circ}$ 610); Centeno, 1987, 117 (n. ${ }^{\circ}$ 50); Lopo, 1987, 139; Gonçalves 1992-93, 196-197 (n. $\left.{ }^{\circ} 28\right)$.

\section{Muro/Crasto, Pastoría, Redondelo, Chaves}

(CMP 1:25.000 n. ${ }^{\circ}$ 46; Coord. Gauss: M-247.5/P-529.4; Alt.: 608m)

$\mathrm{O}$ povoado localiza-se num remate de esporão, a meia encosta, na vertente sudoeste da plataforma Elhos-Facho, na parte superior da ribeira da Curalha.

Três linhas de muralha com origem num ponto comum, a este, onde surgem adossadas entre si, conformam um povoado de contorno ovalado ao prolongarem-se, acompanhando o declive do terreno, para sudeste, atingindo nos sentidos NW-SE e NE-SW, 100 e $60 \mathrm{~m}$, respectivamente, de dimensão máxima. As muralhas são constituídas por dois paramentos, de blocos graníticos bem aparelhados e colocados a seco, sendo o espaço intermédio preenchido com pedra miúda.

A defesa, no lado nascente, o voltado à serra, é reforçada por um fosso e, muito possivelmente, por uma área de pedras fincadas exterior ao fosso, indiciada por alguns blocos dispersos.

Esta estação arqueológica foi objecto de um estudo mais apurado, em 1982-83, dirigido por T. Soeiro, tendo-se, então, sondado duas áreas do povoado: no lado nascente, foi efectuado um corte na estrutura amuralhada, tendo-se comprovado a união das três linhas de muralha nesse lado; no espaço interior à última muralha, do lado oposto do povoado, foram escavadas duas valas de sondagem que permitiram descobrir uma construção circular, com 4,5 m de diâmetro, de que se conservavam pequenos esteios rectangulares enterrados no saibro, acompanhados de pequenas pedras e blocos de barro que formariam as paredes da cabana, contendo no seu interior restos de trabalho do ferro e uma mó manuária circular.

Do espólio recolhido durante as sondagens destacam-se: os muitos vestígios relacionados com a metalurgia do ferro - $35 \mathrm{Kg}$ de pequenos blocos 
de ferro, associados à cabana, e restos de revestimento interior de um forno ligado à metalurgia do ferro - e do bronze - pedaço de bronze informe; duas fíbulas, uma de tipo Sabroso, recolhida no interior da cabana, e outra de tipo zoomórfico, recolhida à superfície, igualmente no interior da última muralha; mós manuárias; cossoiros; um agrafe em ferro; e fragmentos de um, ou mais, fornos de cozedura de cerámica e fragmentos cerâmicos (talhas, púcaros e um vaso de asa interior). É apontado o século I a. C. como cronologia integradora dos vestígios materiais exumados, embora esta possa corresponder apenas a uma das fases da ocupação do sítio.

BIBLIOGRAFIA: Azevedo 1901, 236 (n. ${ }^{\circ} 404$ ); Sampaio 1929; Montalvão 1971; Martins 1980b; 1984(n. $\left.{ }^{\circ} 29\right)$; 1985, 17-18; Soeiro 1985-1986; Silva 1986, 91 (n. $\left.{ }^{\circ} 520\right)$; Amaral 1993, 59-60 (n. ${ }^{\circ} 85$ B).

\section{Castro (Castro da Curalha)/Castelo/Cerca, Curalha Chaves}

(CMP 1:25.000 n. ${ }^{\circ}$ 47; Coord. Gauss: M-250.3/P-526.8; Alt.: 436m)

Implanta-se num cabeço pouco pronunciado de uma encosta de pendor suave do rebordo inferior da vertente sudoeste da superfície de Sanjurge, próximo da ribeira da Curalha, na sua afluência ao rio Tâmega. $O$ povoado foi intervencionado ao longo de 10 campanhas de trabalho, realizadas entre 1971 e 1984, sob a responsabilidade de J. Santos Júnior e A. Medeiros de Freitas, aos (quais se associou, nos primeiros trabalhos, Adolfo Magalhães.

Apresenta três linhas de muralha, sendo duas delas concêntricas. A primeira define um recinto central de configuração elíptica com uma extensão máxima de $90 \mathrm{~m}(\mathrm{~N}-\mathrm{S})$ por $120 \mathrm{~m}(\mathrm{E}-\mathrm{W})$. Esta muralha, que atinge uma largura de, aproximadamente, $5 \mathrm{~m}$, dispõe de cinco rampas de acesso pelo seu interior e três entradas, situadas a norte, este e sudoeste. No interior deste recinto foi individualizado um conjunto de casas, quase todas de planta rectangular, à excepção de duas, uma quadrangular e outra circular, construídas sobre um afloramento granítico, dominando todo o recinto amuralhado. As restantes casas, todas de desenho rectangular ou subrectangular, parecem orientar-se segundo arruamentos: de um lado e de outro da entrada nascente alinham-se, encostadas à muralha e partilhando entre si uma parede divisória (meeira), duas correntezas de casas cujas aberturas se voltam para arruamentos, executados com lajes de granito, que seguem paralelos à muralha e que entroncam num outro que serve a entrada do recinto e circunda o afloramento rochoso, aparentemente, por ambos os lados; outras casas isoladas têm a mesma relação com a muralha; no centro do recinto, a noroeste da casa quadrangular, existe um outro conjunto de casas, alinhadas segundo a direcção NE-SW, que partilham igualmente paredes meeiras e têm todas as aberturas voltadas para o mesmo lado, o que faz suspeitar da existência de um outro arruamento. 
A segunda linha de muralha, com um perímetro de $325 \mathrm{~m}$ e uma espessura média de $2 \mathrm{~m}$, mas variável, pontualmente, entre os 1,50 e os $3,30 \mathrm{~m}$, envolve a primeira, a uma distância que oscila entre os 2,50 e os $11,60 \mathrm{~m}$, dispondo apenas de uma entrada voltada a nor-nordeste. Tem duas rampas de acesso na face interna. Em alguns tramos encontra-se construída sobre o afloramento granítico previamente talhado de forma a garantir maior solidez ao assentamento das pedras. No lado sul, dois muros perpendicularmente ligados à muralha parecem indiciar a existência de duas construções de planta rectangular. Da terceira muralha apenas há testemunho, a noroeste, de um pequeno tramo com $9 \mathrm{~m}$ de extensão que dista $4 \mathrm{~m}$ (máximo) da segunda linha defensiva. A construção das muralhas é feita mediante o levantamento de dois paramentos de blocos de granito aparelhados, colocados a seco, e o enchimento do espaço intermédio com pedra miúda.

Um extenso campo de pedras fincadas posicionado entre o nascente e o nordeste, ao longo de, aproximadamente, sete dezenas de metros e com um comprimento de uma centena de metros, completa a defesa do povoado no sector menos defensável; apesar de parcialmente destruído, subsistem, todavia, tufos destas pedras, com alturas médias acima do solo que oscilam entre os $0,10 \mathrm{~m}$ e os $0,30 \mathrm{~m}$ (alguns exemplares atingem os $0,50 \mathrm{~m}$ ), que indiciam que este sistema defensivo ocuparia uma área considerável em frente da segunda linha de muralha, onde, por vezes, se combina com afloramentos graníticos que pontuam a área.

O espólio proveniente das várias campanhas de trabalho arqueológico é constituído por cerâmicas de construção romanas (tegulae, imbrices, tijoleiras), cossoiros, vidros (esverdeados e incolores), escórias, peças em bronze, mós manuárias circulares, fragmentos de terra sigillatta (clara e estampada), abundante cerâmica comum, alguma, pelas pastas e decorações, claramente, da Alta Idade Média (séculos VI e VII) e moedas, nomeadamente do século IV.

A topografia do povoado, o conjunto de materiais existente e as particularidades da sua organização interna, mormente a existência de habitações de planta rectangular com paredes divisórias comuns, encostadas à muralha e voltadas para arruamentos, parecem atribuir-lhe uma ocupação tardia, na Baixa Romanidade e Alta Idade Média.

BIBLIOGRAFIA: Argote 1734, 496-497; Vasconcelos 1917, 22; Montalvão 1971, 94, 7-12; Magalhães et alii 1975; 1977; 1978; Almeida 1979, 313; Esparza Arroyo 1980, 76 (n. ${ }^{\circ}$ 15); Luzon Nogué et alii 1980, 81 e 82 (n. ${ }^{\circ}$ 9); Freitas e Santos Júnior 1980; 1981; 1982; 1983; 1984; Santos Júnior 1984b; Santos Júnior e Freitas 1985; Silva 1986, 91 (n. ${ }^{\circ}$ 522); Amaral 1993, 39-40 (n. $\left.{ }^{\circ} 33 \mathrm{~B}\right)$.

Conimbriga, 39 (2000) 5-51 


\section{Castelo de Vilarelho, Alijó}

(CMP 1:25.000 n. ${ }^{\circ}$ 116; Coord. Gauss: M-253,6/P-479,0; Alt.: 800m)

O povoado assenta num castelo rochoso situado no sector sul do planalto de Alijó, próximo do rio Douro, dispondo de amplo controlo geo-estratégico sobre os relevos e os vales mais baixos.

O sistema defensivo é composto por duas linhas de muralha, um torreão, um fosso e um campo de pedras fincadas. O torreão foi construído no ponto mais alto do local de assentamento, desenvolvendo-se a partir dele uma linha de muralha de perímetro semicircular pelos lados poente, ao longo da cumeada, sul, descendo a encosta, e oeste. A segunda linha de muralha entronca na primeira nos cantos sul e norte, delimitando um amplo recinto de inclinação suave, no lado sudoeste. A largura das muralhas, construídas com dupla face e interior preenchido por blocos de pedra partida, é variável, ultrapassando, por vezes, os $4 \mathrm{~m}$. No interior dos dois recintos observam-se derrubes dispersos. No lado que permite um acesso mais favorável jazem restos de um campo de pedras fincadas cujo carácter defensivo seria reforçado por um fosso, actualmente colmatado.

O espólio recolhido é constituído por alguns fragmentos de cerâmica de fabrico manual atribuíveis à Idade do Ferro e por materiais de cronologia romana que Brochado de Almeida e M. Plácido consideram estarem em sincronia com o estilo do aparelho das muralhas.

BIBLIOGRAFIA: Maranhão 1836; Botelho 1896, 266; Arião 1908, 64; Almeida e Plácido 1983, 49 e 51; Silva 1986, 95 (n. 621); Lopo 1987, 13; Lemos 1993, Ilb, 462-463.

\section{Castelo dos Mouros, Vale de Égua, Jou, Murça}

(CMP 1:25.000 n. ${ }^{\circ}$ 75; Coord. Gauss: M-261,3/P-503,8; Alt.: 590m)

Povoado fortificado localizado no extremo sudoeste da veiga de Lila, sobranceiro a um afluente da ribeira de Lila.

As características naturais do esporão onde se instala este povoado impõem-lhe uma configuração alongada. A poente foi aproveitada uma comprida bancada rochosa, transversal ao vale, que proporcionou uma redução substancial do esforço de fortificação, dado que apenas são construídos pequenos troços de muralha nos poucos intervalos entre afloramentos, ao mesmo tempo que impõe a esse lado do povoado uma configuração quase rectilínea; do extremo setentrional desta bancada rochosa arranca, em direcção ao norte, um não muito comprido pano de muralha quase rectilíneo que em seguida inflecte para sudeste passando a descrever um traçado suavemente curvo que vai convergindo para a bancada rochosa até definitivamente inflectir ao encontro do seu extremo meridional. 
A muralha apresenta uma largura variável entre os 2 e os $3 \mathrm{~m}$ e em alguns pontos conserva-se com mais de $2 \mathrm{~m}$ de altura, apesar de construída em alvenaria ensossa de xisto.

$\mathrm{O}$ acesso ao interior do povoado era efectuado por duas portas marcadas por encurvamentos da muralha para o interior: uma, voltada a nordeste, posiciona-se sensivelmente a meio do seu traçado nascente e a outra, voltada a sudeste, está colocada no ponto de inflexão da muralha para sul.

O sector de muralha voltado a setentrião é antecedido de dois sucessivos terraplenos em arco, desnivelados 0,70 a $0,80 \mathrm{~m}$ e com um comprimento que ronda a meia centena de metros, que o envolvem em toda a extensão. A criação da plataforma superior, com uma largura máxima de $15 \mathrm{~m}$, exigiu a construção de suporte às terras com lajes de pedra de xisto e quartzito e areia; o terrapleno inferior, com uma largura máxima de $14 \mathrm{~m}$, acolhe um campo de pedras fincadas (xisto e quatzito), com alturas variáveis entre os 0,15 e os $0,40 \mathrm{~m}$, que se concentra encostado ao seu limite exterior e estrategicamente voltado para o colo de acesso ao povoado, numa extensão de $20 \mathrm{~m}$ de comprimento e 6 a $7 \mathrm{~m}$ de largura, mas que poderia ter sido mais vasta.

No interior do recinto amuralhado, que se apresenta com suave pendor para sudeste, identificam-se estruturas habitacionais de planta quadrangular e rectangular também construídas em lajes de xisto sobrepostas. O espólio associado a este local é constituído por fragmentos de cerâmica romana de uso comum e de construção, nomeadamente de tegulae, mas também por uma escória e fragmentos de um grande dolium recolhidos por Sande Lemos num buraco aberto no interior de uma das referidas estruturas habitacionais.

Como sugere este autor, o sítio deve corresponder a um povoado mineiro fortificado, de tipologia semelhante à dos castros de $\mathrm{O}$ Courel, e com analogias no Castelo de Macedinho (Mirandela) no que respeita à estrutura defensiva e às construções adossadas à muralha, a partir do qual se fariam pequenas explorações dos filões de quartzo aurífero das imediações, sendo datável da época romana.

BIBLIOGRAFIA: Lemos 1993, Ilb, 493-495 (n. $\left.{ }^{\circ} 844\right) ; 1996,149$.

\section{Murada de Lama do Ouriço, Lama de Ouriço, Alvarelhos, Valpaços}

(CMP 1:25.000 n. ${ }^{\circ} 48$; Coord. Gauss: M-266,5/P-525,7; Alt.: 730m)

O povoado está implantado num relevo em esporão que lhe confere um razoável controlo sobre o planalto e a depressão que se abre pelo lado norte.

A ausência de boas condições naturais de defesa exigiu a construção de um elaborado sistema defensivo constituído por três linhas de muralha: a interna, que define um recinto subcircular com um torreão voltado a nascente; a intermédia que, unida à anterior, se desenvolve entre aquele lado 
e o poente, limitando um recinto de dimensão ainda considerável totalmente voltado a sul; e a externa, que envolve as anteriores, apresentando no lado nascente a particularidade de configurar um alinhamento côncavo que se aproxima das estruturas defensivas internas. Apenas no lado poente foi possível reduzir o esforço de fortificação pelo aproveitamento dos poucos afloramentos graníticos aí emergentes.

Vislumbram-se duas entradas na muralha interna, uma ortogonal no seu sector nascente e outra oblíqua no poente, e uma terceira, também oblíqua, no sector poente do circuito intermédio.

A defesa do lado nascente do povoado era complementada por um campo de pedras fincadas, possivelmente antecedendo um fosso artificial. Os vestígios observados indiciam a sua existência ao longo de todo o sector nascente da muralha externa, porém é notória a sua maior concentração na metade sul deste sector, onde mais facilmente se poderia acercar o inimigo. As pedras conservadas apresentam alturas variáveis entre os 0,20 e os $0,70 \mathrm{~m}$ e em alguns pontos convivem com pequenos afloramentos graníticos que também constituem naturais obstáculos.

As muralhas, de espessura variável entre os 3 e os $4 \mathrm{~m}$, são estruturadas por dois paramentos construídos com blocos graníticos rectangulares ou triédricos, ou com simples pedras talhadas, dispostos a intervalos irregulares, e o seu interior é preenchido por pedras miúdas, e outras de média dimensão, misturadas com terra.

No interior e no exterior do povoado detectam-se vestígios de casas de planta circular e rectangular.

O espólio recolhido no interior do povoado é escasso, reduzindo-se a parcos fragmentos cerâmicos proto-históricos de fabrico manual; porém, na área extramuros, a sudoeste, de acordo com F. Sande Lemos, ocorrem fragmentos de cerâmica de construção romana, associados a construções.

BIBLIOGRAFIA: Castro Lopo 1954, 18-19; Montalvão 1971, 52-58; Veloso Martins 1978, 53 e 65-66; Martins 1984 (n. 19); Silva 1986, 93 (n. $\left.{ }^{\circ} 571\right)$; Lemos 1993, Ilb, 505-507 (n. $\left.{ }^{\circ} 854\right) .{ }^{11}$

\section{Murada/Cidade do Muro, Fiães, Valpaços}

(CMP 1:25.000 n. ${ }^{\circ}$ 35; Coord. Gauss: M-270,6/P-530,3; Alt.: 740m)

Povoado instalado num relevo pouco destacado, no extremo nascente do Planalto de Fiães, próximo da ribeira de Nozelos. O seu posicionamento estratégico confere-lhe um bom controlo do território envolvente, embora não lhe confira especiais condições naturais de defesa.

Apresenta três linhas de muralha, definindo a principal um recinto de planta subcircular, com suave pendente para poente, a partir de um torreão que 
reforça a defesa do povoado do lado oriental; duas outras linhas de muralha, em arco, adossam-se ao circuito muralhado principal nos lados sul e oeste, delimitando duas pequenas plataformas adjacentes ao recinto principal e contribuindo para o reforço da sua muralha. As muralhas, que têm, por vezes, mais de $4 \mathrm{~m}$ de espessura, apresentam dois paramentos construídos com pedras de granito, partidas ou com um aparelhamento bastante fruste, assentes a seco, cujo interior é cheio com pedras e terra; nota-se uma maior qualidade construtiva no paramento externo dos arcos de muralha com o uso de blocos rectangulares dispostos em fiadas certas.

Os trabalhos de fortificação estenderam-se ainda à escavação de fossos que reforçam a defesa do povoado a nascente, em frente ao torreão, e a norte. Neste lado, o fosso, que aparece dissimulado por uma cortina de afloramentos graníticos pouco elevados, é antecedido por um campo de pedras fincadas, a linha defensiva mais externa, num sector onde a topografia ligeiramente inclinada não é suficiente para impedir o acesso ao povoado a partir do vale da ribeira de Nozelos. As pedras conservadas, com alturas variáveis entre os 0,05 e os 0,65 m, dispõem-se de forma compacta, ocupando os espaços livres entre os afloramentos, nos 20 a $25 \mathrm{~m}$ que precedem o fosso e ao longo de todo o seu comprimento, que se aproxima dos $40 \mathrm{~m}$.

O espólio recolhido no interior do povoado resume-se a escassos fragmentos de cerâmica manual, sem decoração, atribuíveis à Idade do Ferro.

BIBLIOGRAFIA: Montalvão 1971, 66-68; Martins 1984 (n. ${ }^{\circ}$ 6); Silva 1986, 93 (n. ${ }^{\circ}$ 569); Lemos 1993, Ilb, 525-526 (n. $\left.{ }^{\circ} 875\right)$.

\section{Múrio de Penhas Juntas, Penhas Juntas, Vinhais \\ (CMP 1:25.000 n. ${ }^{\circ}$ 49; Coord. Gauss: M-291,5/P-529,5; Alt.: 700m)}

Um esporão com boas defesas naturais, localizado no extremo leste do Serro de Penhas Juntas, constitui o local de assentamento deste pequeno povoado fortificado.

$\mathrm{Na}$ zona de acesso ao esporão, um fosso antecede um torreão circular, a partir do qual se desenvolve a única linha de muralha que defende o recinto elíptico. A muralha é construída com pedra de xisto partida e terra. Alves e Lopo referem a existência de pedras fincadas, com cerca de $1 \mathrm{~m}$ de altura acima do nível do solo, a reforçar a estrutura defensiva do povoado, as quais não foram identificadas por Lemos. Os mesmos autores referiram ainda a existência de vestígios de casas construídas, presumivelmente, em pedra de xisto assente a seco.

O espólio associado ao povoado reduz-se a alguns fragmentos de mós manuárias e a escassos fragmentos de cerâmica da Idade do Ferro. 
BIBLIOGRAFIA: Alves 1931, 39; 1934, 539-540; Neto 1975, 330; Esparza Arroyo 1980, 76 (n. $\left.{ }^{\circ} 18\right)$; Luzon Nogué et alii 1980, 82 (n. $\left.{ }^{\circ} 11\right)$; Tranoy 1981, 86; Silva 1986, 96 (n. ${ }^{\circ}$ 652); Lopo 1987, 159; Lemos 1993, Ha, 437-438 (n. $\left.{ }^{\circ} 235\right)$.

\section{Monte de Santa Comba, Ousilhão, Vinhais}

(CMP 1:25.000 n. ${ }^{\circ}$ 37; Coord. Gauss: M-296,9/P-536,8; Alt.: 917m)

Povoado fortificado da Idade do Ferro, assente num local com boas condições naturais de defesa, que oferece um óptimo controlo geo-estratégico e uma ampla visibilidade sobre o território adjacente.

O povoado divide-se em dois recintos: a uma cota superior, um recinto com uma configuração oblonga é delimitado por uma muralha que segue, grosso modo, a configuração do terreno; do lado sudeste, há uma segunda plataforma, a uma cota inferior, defendida por outra muralha que se une à superior.

A defesa é completada, do lado norte, por um parapeito, um fosso e um campo de pedras fincadas. O fosso foi escavado no solo rochoso, e os materiais resultantes da sua escavação permitiram a construção do parapeito, entre o fosso e a muralha, que o acompanha em toda a sua extensão. Na periferia destas defesas estende-se o campo de pedras fincadas que parece ter ocupado uma área considerável, de 50×20m, aproximadamente.

A abertura de um caminho ao longo da cumeada cortou, sucessivamente, o campo de pedras fincadas, sendo visíveis algumas das pedras fincadas amontoadas nas suas bermas, o fosso, o parapeito e a muralha. Este corte, associado ao posterior aproveitamento da pedra de dois troços da muralha do recinto superior, permitiu verificar que a sua estrutura é constituída por paramento duplo de pedra partida sobreposta, com o interior cheio de pedra pequena e terra.

As pedras fincadas têm uma morfologia e dimensões variadas, havendo uma tendência para que a sua altura regule entre os 40 e os $60 \mathrm{~cm}$; a distância entre elas, medida junto ao solo, não é constante, tendo nós registado a distância mínima de $10 \mathrm{~cm}$ e a máxima de $50 \mathrm{~cm}$. Um aspecto curioso deste campo de pedras fincadas é a complementaridade entre estas pedras e os afloramentos rochosos, isto é, neste espaço eles adquirem a mesma função das pedras fincadas, sendo estas em alguns casos usadas apenas para colmatar, de forma isolada, espaços existentes entre afloramentos mais próximos entre si.

F. Sande Lemos recolheu no local alguns fragmentos de cerâmica manual cujos bordos e decorações os permitem integrar no Bronze Final/I Idade do Ferro e algumas cerâmicas mais evoluídas que atribui a uma fase posterior da Idade do Ferro. 
BIBLIOGRAFIA: Alves 1934, 577 e 643; Neto 1975, 329; Lemos 1993, Ia, 180-182, lia, 433-434 (n. $\left.{ }^{\circ} 228\right)$ e III, est. LXX.

\section{Castelo de Alimonde, Alimonde, Carrazedo, Bragança}

(CMP 1:25.000 n. ${ }^{\circ}$ 37; Coord. Gauss: M-302,9/P-536,8; Alt.: 769 m)

Ocupa um cabeço de vertentes íngremes posicionado nos contrafortes setentrionais da Serra da Nogueira.

O povoado tem uma configuração elipsoidal conferida pelo traçado da sua muralha; esta encontra-se construída com pedra de xisto partida e deriva de um torreão circular edificado do lado sul. O sistema defensivo é ainda composto por um fosso, exterior à muralha, escavado em frente ao torreão e por um campo de pedras fincadas do lado poente.

Um insólito asse (?) de Augusto, Tibério ou Gaio (27 a. C.-41 d. C.), cunhado em Bilbilis, constitui o único achado proveniente deste povoado.

BIBLIOGRAFIA: Cruz 1897, 100; Alves 1934, 474; Neto 1975, 189; Centeno 1987, 100 (n. ${ }^{\circ}$ 1); Lemos 1993, Ila, 56-57 (n. $\left.{ }^{\circ} 30\right)$.

\section{Castelo (de Parada)/Castelo da Marruça, Parada, Alfândega da Fé}

(CMP 1:25.000 n. ${ }^{\circ}$ 106; Coord. Gauss: M-306,4/P-483,2; Alt.: 490m)

$\mathrm{O}$ povoado assenta num cabeço dotado de boas condições defensivas naturais e de bom posicionamento geo-estratégico. As vertentes deste cabeço, sobranceiro ao rio Sabor, situado na parte oriental da Serra de Bornes, apresentam-se em arriba.

Uma única linha de muralha circunda o cabeço, unindo-se aos afloramentos xistosos que já por si oferecem condições naturais de defesa, dando ao povoado uma configuração irregular. A muralha, que foi construída com pedra de xisto partida, assente a seco, tem uma espessura de cerca de $3 \mathrm{~m}$ e conserva, em alguns pontos, uma altura de também $3 \mathrm{~m}$. Um campo de pedras fincadas e um fosso completam a defesa no lado mais acessível do povoado.

Não existe qualquer espólio proveniente deste povoado.

BIBLIOGRAFIA: Alves 1934, 149 e 491; Neto 1975, 179; Silva 1986, 102 (n. $\left.{ }^{\circ} 780\right)$; Lemos 1993, Ila, 25-26 (n. $\left.{ }^{\circ} 509\right)$.

\section{Cidadelhe, Parada de Infanções, Bragança}

(CMP 1:25.000 n. ${ }^{\circ}$ 51; Coord. Gauss: M-317,4/P-523,3; Alt.: 902 m)

O povoado está implantado num cabeço do interior do planalto de Parada/Izeda que lhe concede um bom controlo geo-estratégico do planalto. 
As suas defesas naturais são escassas. Uma muralha de pedra partida e terra delimita o cabeço formando um recinto de planta subcircular. Do lado sudoeste a muralha limita-se a preencher os espaços entre os afloramentos. O seu sistema defensivo apoia-se ainda em dois fossos, um que rodeia a muralha pelo poente, sul e sudeste e outro, cortado no afloramento rochoso, a noroeste, e em dois conjuntos de pedras fincadas. Um destes conjuntos ocupa o espaço compreendido entre o fosso do lado noroeste e a muralha e o outro ocuparia uma área exterior ao fosso, no lado sudeste. De acordo com Harbinson, o conjunto setentrional teria $2 \mathrm{~m}$ de largura e as suas pedras cerca de $30 \mathrm{~cm}$ de altura, enquanto que as do meridional atingiriam $1 \mathrm{~m}$.

Do lado norte, o aproveitamento da pedra das muralhas danificou bastante as estruturas arqueológicas, no entanto ainda pudemos observar, contrariamente a Sande Lemos, pedras fincadas, algumas não atingindo os $20 \mathrm{~cm}$ de altura, que parecem corresponder às referenciadas por Harbinson. A abertura do fosso no afloramento rochoso poderá ter proporcionado a pedra aqui utilizada.

Do lado sudeste, não lográmos identificar as pedras fincadas assinaladas pelo arqueólogo irlandês, apesar das investidas pelo interior do denso mato e da sua dimensão poder facilitar a tarefa; porém, a inspecção do fosso desse lado permitiu-nos detectar alguns blocos pétreos cuja forma e dimensão indiciam tratar-se de pedras fincadas, o que também está de acordo com as informações de Harbinson ao referir-se a um entulhamento moderno do fosso, no qual poderiam ter sido utilizadas algumas pedras fincadas; quanto às que ainda estariam a bordejar o fosso acreditamos que pudessem ter desaparecido, volvidos trinta anos de continuada exploração de pedra.

Fazendo fé no relato de A. Lopo, talvez pudéssemos pensar que as barreiras de pedras fincadas fossem mais extensas, pois ele informa que nas partes mais acessiveis havia mais de uma linha de defesa; e no intervalo entre elas, e em toda a volta pedras postas a pino embaraçavam a aproximação e os movimentos do atacante.

O espólio por nós identificado é constituído por fragmentos cerâmicos, a maioria deles incaracterísticos, que não nos permitem, por ora, estabelecer qualquer valoração de carácter cronológico ou cultural. Alves fala do aparecimento de argolas de metal amarelo (?), que supõe em cobre ou bronze, bem como de mós manuárias em granito, tijolos, telhas, cerâmica grosseira e "saguntina", apesar de nós não termos detectado qualquer indício de romanização.

BIBLIOGRAFIA: Lopo 1910, 328-333; Alves 1934, 513; Harbinson 1968, 120-122; 1967-68, 385-386; Neto 1975, 201; Esparza Arroyo 1980, 76 (n. ${ }^{\circ}$ 17); Luzon Nogué et alii 1980, 82 (n. $\left.{ }^{\circ} 12\right)$; Silva 1986, 98 (n. ${ }^{\circ}$ 696); Lopo 1987, 62-63; Lemos 1993, lia, 113-114 (n. $\left.{ }^{\circ} 100\right)$ e III, est. LXXII, 2. 
17. Castro de Alfaião/Cabecinho dos Mouros, Alfaião, Bragança

(CMP 1:25.000 n. ${ }^{\circ}$ 38; Coord. Gauss: M-317,3/P-533,0; Alt.: 540m)

$\mathrm{O}$ povoado ocupa um relevo em esporão, de vertentes íngremes, sobranceiro à ribeira do Penacal, já próximo da sua confluência com o rio Fervença.

O espaço interno do povoado, de forma elíptica, é delimitado por uma muralha, construída com pedra de xisto partida e terra, que no lado poente, o único que proporciona acesso fácil ao povoado, se une a um torreão de planta subcircular. O sistema defensivo do povoado dispõe, ainda, de dois fossos consecutivos, talhados na rocha, que ladeiam a face externa da muralha em frente ao torreão, cortando o acesso ao esporão. De acordo com o testemunho do Pe. Luiz Cardoso teria para a parte do sul como estacada de pedras de louza feita ao antigo, isto é, uma área de pedras fincadas, como interpreta F. M. Alves. Não encontrámos qualquer vestígio das pedras fincadas; tomando por base a referência de Cardoso, poderemos admitir ter existido uma barreira daquelas pedras na área envolvente dos fossos, entre o Sul e o Norte.

Sande Lemos recolheu um fragmento de um vaso liso com carena, que atribui à Idade do Ferro.

BIBLIOGRAFIA: Cardozo 1747, 272; Pinheiro 1895, 55; Figueiredo 1895, 241-243; Lopo 1910, 332; 1987, 18-19; Alves 1934, 105, 180 e 492; Neto 1975, 198; Esparza Arroyo 1980, 76 (n. 11); Silva 1986, 98 (n. ${ }^{\circ}$ 684); Lopo 1987, 19; Lemos 1993, lia, 35 (n.ำ 1), Ia, 191e III, est. LXXVII, 3.

\section{Castelo Velho de Lagoaça, Lagoaça, Freixo de Espada-à-Cinta \\ (CMP 1:25.000 n. ${ }^{\circ}$ 132; Coord. Gauss: M-318,3/P-467,6; Alt.: 514m)}

Ocupa um esporão, sobranceiro ao rio Douro, que lhe confere boas condições naturais de defesa.

A construção de defesas artificiais ficou limitada ao istmo de acesso, onde foi levantado um arco de muralha, com pedra granítica miúda de aparelho tosco, que isola a área do esporão; possivelmente, em frente a este arco de muralha, existiu um fosso, actualmente dissimulado pelos trabalhos agrícolas, e um campo de pedras fincadas, que Lemos não logrou identificar.

O espólio proveniente deste povoado resume-se a fragmentos de cerâmica manual da Idade do Ferro.

BIBLIOGRAFIA: Esparza Arroyo 1980, 76 (n. ${ }^{\circ}$ 16); Lemos e Martins 1982; Lemos 1993, lia; 165 (n. ${ }^{\circ}$ 573).

\section{Cabeço da Coroa, Sampaio, Azinhoso, Mogadouro \\ (CMP 1:25.000 n. ${ }^{\circ}$ 93; Coord. Gauss: M-319,2/P-496,4; Alt.: 512m)}

Povoado sobranceiro ao rio Sabor, implantado no topo de um cabeço 
de forma alongada com razoáveis condições naturais de defesa, sobretudo a norte e nordeste, no rebordo ocidental do planalto de Miranda.

O recinto, de média dimensão, é delimitado por uma única linha de muralha de pedra de xisto partida, à qual se associa um campo de pedras fincadas no sector este.

Não existe registo de qualquer espólio associado ao povoado.

BIBLIOGRAFIA: Alves 1934, 153; Neto 1975, 274; Lemos 1993, lia, 273-274 (n. $\left.{ }^{\circ} 353\right)$; Marcos 1994, 111.

20. Castelo (de Calvelhe)/Castro, Calvelhe, Bragança

(CMP 1:25.000 n. ${ }^{\circ}$ 65; Coord. Gauss: M-319,9/P-515,1; Alt.: 600m)

Povoado implantado num relevo em esporão, sobranceiro ao vale profundo da ribeira de Viados, afluente do rio Sabor.

A topografia deste esporão ditou a forma irregular do povoado que é delimitado por uma muralha, construída com pedra de xisto sobreposta, que arranca de um torreão subcircular voltado para o lado de acesso ao esporão; neste sector, fronteiro ao torreão, a estrutura defensiva é reforçada por um fosso aberto no substrato rochoso e, entre este e o torreão, por um campo de pedras fincadas, parcialmente conservado.

Não se regista qualquer achado de espólio arqueológico.

BIBLIOGRAFIA: Alves 1934, 142 e 180; Harbinson 1968, 122; 1967-68, 387-388; Neto 1975, 188; Esparza Arroyo, 1980, 76 (n. $\left.{ }^{\circ} 13\right)$; Luzon Nogué et alii 1980, 82 (n. ${ }^{\circ}$ 14); Tranoy 1981, 86; Silva 1986, 98 (n. ${ }^{\circ}$ 700); Lemos 1993, lia, 54-55 (n. $\left.{ }^{\circ} 27\right)$.

\section{Castelo Velho/Castelo dos Mouros, Bruçó, Mogadouro}

(CMP 1:25.000 n. ${ }^{\circ}$ 120; Coord. Gauss: M-321,0/P-472,9; Alt.: 720m)

Povoado implantado numa arriba sobranceira ao vale do rio Douro com excelentes condições naturais de defesa, aliadas a um bom posicionamento estratégico.

Dispõe de um sistema defensivo composto por uma única linha de muralha que circunda a plataforma de assentamento, excepto pelo lado nascente, onde a arriba a dispensa, e por um campo de pedras fincadas, um fosso e um torreão subcircular que reforçam a defesa e permitem o controlo da zona de acesso, a norte. A muralha é construída com pedra irregular de granito e tem, nalguns pontos, $1,80 \mathrm{~m}$ de largura. No seu interior vislumbram-se, segundo Marcos, vestígios de habitações.

O espólio proveniente deste povoado reduz-se a escassos fragmentos de cerâmica de fabrico manual.

Conimbriga, 39 (2000) 5-51 
BIBLIOGRAFIA: Alves 1934, 140; Neto 1975, 277; Silva 1986, 102; Lemos 1993, Ha, 275-276 (n. $\left.{ }^{\circ} 357\right)$; Marcos 1994, 112.

\section{Castro de Babe/Castro da Sapeira, Babe, Bragança}

(CMP 1:25.000 n. ${ }^{\circ}$ 38; Coord. Gauss: M-322,3/P-539,2; Alt.: 896m)

Povoado de média dimensão implantado num relevo em esporão sobranceiro à ribeira da Sapeira com amplo domínio visual sobre o vale do rio Sabor, a sul, e o planalto, que se estende para nordeste.

Apresenta uma configuração oblonga definida por uma linha de muralha construída com pedra de xisto quartzoso e terra que, sobretudo de noroeste a nascente, se vai amparando nos fraguedos que limitam o esporão. $\mathrm{O}$ seu interior está dividido em três plataformas escalonadas que, pelas evidências conservadas, pese embora a grande dificuldade de observação devido ao denso mato que as recobre, não nos parecem separadas por linhas de muralha propriamente ditas. A plataforma superior corresponde a um recinto que abarca um conjunto de afloramentos no sector sudoeste do povoado; um conjunto de derrubes pouco expressivos que surgem por entre os afloramentos delineiam uma linha curva, entre o noroeste e o sul, que delimita o recinto. Uma outra linha curva marcada por um desnível e um alguns grandes blocos pétreos (socalco?), entre o norte e o sudeste, constitui o limite entre as plataformas intermédia e inferior, a mais oriental.

No exterior da muralha, entre sudoeste e sul, permanecem vestígios de uma extensa barreira de pedras fincadas que conserva uma largura aproximada de $15 \mathrm{~m}$ e um comprimento que ultrapassa ligeiramente os $100 \mathrm{~m}$, ainda que verosimilmente pudesse ter sido maior, dado que as pedras fincadas se deveriam também estender ao sector sudeste do povoado, a um espaço actualmente sob uso agrícola e que, verdadeiramente, está voltado ao planalto. As pedras fincadas conservam alturas médias acima do solo que oscilam entre os 0,10 e os 0,40 m, embora uma minoria possa atingir alturas superiores (entre 0,70 e $0,80 \mathrm{~m})$.

A parte meridional do povoado encontra-se bastante destruída devido à exploração de pedra a que foi sujeita num passado recente; a destruição atingiu também a barreira de pedras fincadas, que apenas se conserva onde o mato mais forte a pôde proteger.

Não se conhece qualquer espólio associado ao povoado.

BIBLIOGRAFIA: Lopo 1898, 341; Beça 1915, 92; Alves 1934, 41; Neto 1975, 184; Silva 1986, 97 (n. ${ }^{\circ}$ 673); Lopo 1987, 40; Lemos 1993, lia, 40-41 (n. $\left.{ }^{\circ} 9\right)$. 
23. Castragosa, Babe, Bragança

(CMP 1:25.000 n. ${ }^{\circ}$ 38; Coord. Gauss: M-325,0/P-537,5; Alt.: 855 m)

Povoado de pequena dimensão implantado num relevo em esporão sobranceiro à ribeira da Ferradosa, sem particulares condições naturais de defesa. Uma única linha de muralha, construída com pedra partida de xisto quartzoso, define um recinto subcircular no topo do esporão. A defesa seria complementada por uma barreira de pedras fincadas exterior à muralha, da qual restam vestígios em alguns pontos do sector ocidental do povoado; o denso carvalhal e os largos derrubes da muralha dificultam a observação dos vestígios deste sistema defensivo que com toda a probabilidade acompanharia a muralha ao longo de todo o sector ocidental, o que oferece um acesso mais favorável, a partir do planalto, devido ao seu declive suave. Os conjuntos de pedras fincadas observados apresentam alturas acima do solo que variam entre os 0,10 e os $0,55 \mathrm{~m}$ e distam menos de $10 \mathrm{~m}$ da linha de muralha.

O espólio associado ao povoado restringe-se a parcos fragmentos de cerâmica manual.

BIBLIOGRAFIA: Alves 1934, 41 e 467; Neto 1975, 200; Silva 1986, 98 (n. ${ }^{\circ} 686$ ); Lemos 1993, lia, 39-40 (n. ${ }^{\circ} 8$ ).

\section{Castelo dos Mouros/Castelinho, Vilarinho dos Galegos, Mogadouro}

(CMP 1:25.000 n. ${ }^{\circ}$ 120; Coord. Gauss: M-327,1/P-477,0; Alt.: 500m)

Povoado assente numa plataforma em arriba sobranceira ao rio Douro, no bordo oriental do planalto de Miranda.

O recinto fortificado é delimitado por uma muralha, construída com pedra de granito picada, na qual se integra um torreão circular, de caras para a zona de acesso, a norte. Nesta zona, a defesa é complementada por um campo de pedras fincadas, ao qual se segue, antecedendo o torreão, um fosso escavado na rocha.

O espólio referente a este povoado compreende fragmentos de cerâmica da Idade do Ferro e fragmentos de cerâmicas comuns e de construção (tegulae) romanas.

BIBLIOGRAFIA: Pereira 1905, 93; Alves 1934, 154, 574 e 666; 1938, 292; Esparza Arroyo 1980, 76 (n. ${ }^{\circ}$ 23); Silva 1986, 102 (n. ${ }^{\circ}$ 797); Bernardo 1989, 30; Lemos 1993, lia, 316-317 (n. $\left.{ }^{\circ} 430\right)$; Marcos 1994, 117-118.

\section{Castelo dos Mouros/Castelo do Mau Vizinho, Algosinho, Peredo de Bemposta, Mogadouro} (CMP 1:25.000 n. ${ }^{\circ}$ 108; Coord. Gauss: M-332,5/P-482,3; Alt.: 675 m) 
O povoado ocupa um relevo em esporão com vertentes escarpadas, sobranceiro à ribeira de Algosinho, afluente do rio Douro, na zona oriental do planalto mirandês. O seu posicionamento no interior de um vale limita-lhe o valor estratégico.

Apresenta uma configuração oblonga, onde as condições naturais de defesa são reforçadas por uma linha de muralha, construída em pedra de granito partida e sobreposta, que circunda o esporão e se combina, no lado ocidental, com os afloramentos graníticos existentes; no lado sul, voltado ao istmo de acesso, um torreão circular integra-se e sela esta linha de fortificação. No exterior, em frente ao torreão, foi escavado na rocha um fosso que é antecedido por uma barreira de pedras graníticas fincadas no solo, que atingem os $0,70 \mathrm{~m}$ de altura, com cerca de $9,50 \mathrm{~m}$ de extensão.

$\mathrm{O}$ espólio associado a este povoado restringe-se a alguns fragmentos de cerâmica manual, embora existam referências ao achado de uma escultura zoomórfica, nos finais do século XIX, e de uma fíbula, entretanto desaparecidas, que poderão estar com ele relacionadas.

BIBLIOGRAFIA: Pereira 1905, 114-115; Alves 1934, 107-108 e 573; Harbinson 1968, 122-123; 1967-68, 386-387; Santos Júnior 1975b, 456; Esparza Arroyo 1980, 76 (n. $\left.{ }^{\circ} 12\right)$; Luzon Nogué et alii 1980, 82 (n. $\left.{ }^{\circ} 16\right)$; Tranoy 1981, 86; Silva 1986, 102 (n. ${ }^{\circ}$ 796); Lopo 1987, 129-130; Lemos 1993, lia, 293 (n. ${ }^{\circ} 393$ ), Marcos 1994, 114-115.

\section{Terronha (de Vimioso)/Castro da Quinta da Furna, Vimioso, Vimioso}

(CMP 1:25.000 n. ${ }^{\circ}$ 66; Coord. Gauss: M-336,2/P-511,3; Alt.: 655 m)

Povoado assente sobre um relevo em esporão, sobranceiro ao rio Angueira, no rebordo oriental do planalto de Algoso-Vimioso.

A estrutura defensiva do povoado conta com duas linhas de muralha, construídas com pedra de xisto partida e terra, que arrancam de um torreão voltado à zona de acesso; a norte, a anteceder a área amuralhada, existiu um campo de pedras fincadas e um fosso.

Não existem referências a espólio arqueológico.

BIBLIOGRAFIA: Alves 1934, 182 e 577; 1938, 293; Alves e Amado 1968, 377 Neto 1975, 320; Silva 1986, 100 (n. ${ }^{\circ}$ 738); Lemos 1993, Ha, 416-417 (n. $\left.{ }^{\circ} 487\right)$; Marcos 1994, 124-125.

\section{Castro/Crasto, S. Martinho de Angueira, Miranda do Douro}

(CMP 1:25.000 n. ${ }^{\circ}$ 67; Coord. Gauss: M-348,2/P-519,5; Alt.: 735 m)

$\mathrm{O}$ povoado tem como lugar de assentamento um relevo em esporão,

Conimbriga, 39 (2000) 5-51 
sobranceiro ao rio Angueira e próximo à ribeira da Matança e do curso de água do Vale de Castro, no limite poente do planalto de Miranda.

O esporão possui condições naturais de defesa, excepto pelo lado sudeste, onde se une com o cabeço de Elvira. Apesar destas características, apresenta um sistema defensivo constituído por duas linhas de muralha (contrariamente a Lemos, Esparza Arroyo e Marcos, que apenas referem uma linha de muralha), fosso e pedras fincadas.

Defendendo o istmo de acesso ao esporão, e antecedendo as linhas de fortificação, foram construídos um campo de pedras fincadas, actualmente destruído, mas que no século XVIII atingia a altura de uma vara, e um fosso. Para lá destas defesas, ergue-se o torreão, solidário com a estrutura amuralhada.

A sua prospecção, facilitada pelas cíclicas práticas agrícolas que atingem o seu interior, permitiu a recolha de espólio cerâmico variado, nomeadamente fragmentos de peças de fabrico manual associáveis ao grupo de Soto de Medinilla; de entre este material cerâmico assumem relevância um fragmento de coador, enquanto indício da prática pecuária - também documentada através de restos osteológicos - e um outro pequeno fragmento com restos de pintura avermelhada, pelo seu interesse cronológico, dado ser atribuível aos séculos VI-V a. C., ambos publicados por Esparza Arroyo. Assinalam-se, ainda, dois cossoiros, duas pequenas pedras polidas e duas bolas cerâmicas também polidas.

Lemos e Marcos referem ainda o achado de materiais romanos, incluindo um número elevado de mós de rodízio, que o primeiro relaciona com a hipótese de exploração de estanho naquele tramo do rio Angueira.

BIBLIOGRAFIA: Cardozo 1747; Figueiredo 1885, 319-3120; Alves 1934, 181; 1938, 67; Neto 1975, 254; Silva 1986, 100 (n. ${ }^{\circ}$ 743); Esparza Arroyo 1986, 143-145; Lemos 1993, lia, 239-240 (n. ${ }^{\circ}$ 336) e III, est. LXXIII e LXXIV; Marcos 1994, 109.

\section{Cigaduenha/Cigadonha/Castro da Calçada, Picote, Miranda do Douro}

(CMP 1:25.000 n. ${ }^{\circ}$ 95; Coord. Gauss: M-351,6/P-492,8; Alt: 680m)

A implantação deste povoado é feita numa plataforma do rebordo oriental do planalto de Miranda sobranceira ao rio Douro, beneficiando da defesa natural proporcionada pelas arribas que a circundam.

O povoado dispõe de um sistema defensivo composto por um campo de pedras fincadas e uma linha de muralha. Esta é construída com blocos graníticos em bruto e apoia-se, de quando em quando, nos afloramentos existentes, fechando a única zona de acesso à plataforma. No exterior da muralha, a norte, foi construído um campo de pedras fincadas cuja imponência motivou, 
em meados do século XVIII, uma descrição pormenorizada no Diccionario Geográfico do Pe. Luiz Cardoso, onde se refere que sobres saião na altura de tres palmos em fileiras com distancia de palmo e meyo de pedra a pedra, interpoladas de forma que as de hua ficavam na direytura dos vãos, e intermeyos da outra deforma, que por ella não se podia caminhar via recta e ainda hoje se conserva parte, de largura de vinte passos com pouca differença.

Apesar das práticas agrícolas terem afectado alguns sectores deste campo de pedras fincadas, é possível ainda hoje confirmar o realismo daquela descrição. Actualmente, as pedras fincadas conservam, acima do solo, alturas compreendidas entre os $0,05 \mathrm{~m}$ e os $0,60 \mathrm{~m}$ e estão colocadas, desencontradas umas das outras, numa faixa com aproximadamente $25 \mathrm{~m}$ de largura que se estende em frente á muralha ao longo de cerca de $80 \mathrm{~m}$, e está dela distanciada 3 a $4 \mathrm{~m}$.

O espólio atribuído a este povoado é constituído por fragmentos de cerâmica manual.

BIBLIOGRAFIA: Cardozo 1747; Vasconcelos 1895, 11-12; Alves 1934, 71-72 e 152; Esparza Arroyo 1980, 76 (n. $\left.{ }^{\circ} 19\right)$; Luzon Nogué et alii 1980, 82 (n. ${ }^{\circ}$ 15); Tranoy 1981, 86; Silva 1986, 101 (n. ${ }^{\circ}$ 766); Bernardo 1989, 20-22; Sanches, 1992, 55 e 153; Lemos 1993, Ila, 228-229 (n. ${ }^{\circ} 327$ ); Marcos 1994, 107-108.

\section{Castrilhouço, Vale de Águia, Miranda do Douro, Miranda do Douro}

(CMP 1:25.000 n. ${ }^{\circ}$ 81; Coord. Gauss: M-356,4/P-506,8; Alt.: 680m)

Povoado localizado num pequeno esporão sobranceiro ao rio Douro, com razoáveis condições naturais de defesa proporcionadas pelas arribas. O sistema defensivo é formado por uma extensa linha de muralha, construída com pedra de granito partida e terra, à qual se associa um torreão posicionado no sector norte do povoado, e por uma área, vestigial, de pedras fincadas, exterior à muralha, na zona de acesso ao esporão. O campo de pedras fincadas guarneceria, outrora, a defesa dos sectores norte e nordeste do povoado, posicionando-se imediatamente em frente do torreão e muralha, onde constituiria a sua defesa mais externa. Identificámos, no sector nordeste, um pequeno núcleo de pedras fincadas, com cerca de $10 \mathrm{~m}$ de comprimento e aproximadamente $5 \mathrm{~m}$ de largura, que parece representar o limite nascente de uma área consideravelmente mais extensa. As pedras observadas conservam alturas acima do solo que variam entre os $0,05 \mathrm{~m}$ e os $0,40 \mathrm{~m}$. A norte, na zona de mais fácil acesso ao povoado, praticamente não existem vestígios do campo de pedras fincadas, à excepção de algumas pedras pontiagudas sobre as quais se levantam os muros de uma construção arruinada que aí jaz, e que, pela sua morfologia, dimensão e implantação, interpretamos como restos do campo de pedras fincadas que assim permanecem selados. O desaparecimento das pedras 
fincadas neste sector, o mais vulnerável, ficou talvez a dever-se ao reaproveitamento dessas pedras na edificação de muros divisórios de propriedades (segundo testemunhos recolhidos por Marcos), ou mesmo nos da construção arruinada que referimos, e à extracção, recente, de saibro nessa zona.

O espólio associado a este povoado é constituído por fragmentos de cerâmica lisa, manual e a torno, atribuíveis à Idade do Ferro, por um cossoiro cerâmico bitroncocónico e um fragmento de um outro em xisto e mós manuais.

BIBLIOGRAFIA: Vasconcelos 1903, 81-83; Alves 1934, 181; 1938, 274; Neto 1975, 249; Silva 1986, 100 (n. ${ }^{\circ}$ 752); Bernardo 1989, 35; Sanches 1992, 54; est. XXVI, XXVII, 1-4; Lemos 1993, lia, 223 (n. ${ }^{\circ}$ 320) e III, est. LXXVI, 3, 6-8; Marcos 1994, 105-106.

\section{Penha da Torre, Paradela, Miranda do Douro}

(CMP 1:25.000 n. ${ }^{\circ}$ 67-A; Coord. Gauss: M-361,7/P-513,6; Alt.: 700m)

Povoado implantado num relevo em esporão sobranceiro ao rio Douro.

O elevado grau de destruição a que foi sujeito provocou o desaparecimento, por completo, das suas defesas. Estas seriam constituídas por uma linha de muralha e um torreão, bem como por uma provável barreira de pedras fincadas que se localizaria no exterior do sector norte do povoado, o mais acessível, de acordo com um testemunho recolhido por Marcos. povoado.

Não é conhecido qualquer espólio arqueológico originário deste

BIBLIOGRAFIA: Lemos 1993, lia, 228 (n. 326); Marcos 1994, 106.

\section{BIBLIOGRAFIA}

ACUÑA, 1996, Fernando Acuña Castroviejo - «Os sistemas de fortificacións nos castros de O Courel (Lugo)», Humanitas (Estudios en Homenaxe ó Prof Dr. Carlos

Alonso del Real, /), Santiago de Compostela, 1996, pp. 319-324

Almagro-Gorbea, 1995, Martín Almagro-Gorbea - «From Hillforts to Oppida in

'Celtic' Iberia», Proceedings of the British Academy, 86, 1995, pp. 175-207

AlmeIDA, 1979, Carlos A. F. Almeida - A propósito de A Galicia Sueva de Casimiro

Torres, Gallaecia, 5, Santiago de Compostela, 1979, pp. 305-316

Almeida e PlÁcido, 1983, C. A. Brochado de Almeida e Manuel Alves Plácido -

«A estela funerária romana da Quinta de S. Jorge. Favaios-Alijó», Arqueologia,

7, Porto, pp. 48-51

ÁlvarEZ-SANCHÍs, 1999, Jesús R. Álvarez-Sanchís - Los Vettones, Bibliotheca

Archaeologica Hispana, 1, Madrid, 1999

Conimbriga, 39 (2000) 5-51 
Alves, 1931, Francisco Manuel Alves - Chaves. Apontamentos Arqueológicos, Gaia, 1931

Alves, 1934, Francisco Manuel Alves, Memorias Arqueológico-Históricas do Distrito de Bragança, IX, Porto, 1934

Alves, 1938, Francisco Manuel Alves, Memorias Arqueológico-Históricas do Distrito de Bragança, X, Porto, 1938

Alves e Amado, 1968, Francisco Manuel Alves e Adrião Martins Amado - Vimioso. Notas monográficas, Coimbra, 1968

Amaral, 1993, Paulo Amaral - O povoamento romano no Vale Superior do Tâmega, dissertação de mestrado policopiada, Porto, 1993

ARgote, 1732-34-44, Jerónimo de Contador Argote - Memorias para a Historia Eclesiástica do arcebispado de Braga, Primaz das Hespanhas, 3 tomos, Lisboa, 1732-1734-1744

ARIÃo, 1908, F. S. Sampaio Arião - «Favaios», Ilustração Transmontana, Porto, 1908, pp. 60-64

Azevedo, 1896, Pedro A. de Azevedo - «Extratos archeologicos das Memorias Parochiaes de 1758» AP, 2 (10-11) e 2 (12), Lisboa, 1896, pp. 252-264 e 305-318

Azevedo, 1901, Pedro A. de Azevedo - «Extratos archeologicos das Memorias Parochiaes de 1758»AP, 6 (3) e 6 (8-12), Lisboa, 1901, pp. 67-78 e 236-240

Azevedo, 1902, Pedro A. de Azevedo - «Extratos archeologicos das Memorias Parochiaes de 1758», AP, 7 (2-3), Lisboa, 1902, pp. 74-79

BEÇA, 1915, Celestino Beça - «Estudos arqueológicos do Major Celestino Beça», AP, 20, Lisboa, 1915, pp. 74-106

Bernardo, 1989, Herminio Augusto Bernardo - «Povoados castrejos portugueses e espanhóis da bacia do Douro internacional», Brigantia, 9 (1), Bragança, 1989, pp. $17-38$

Botelho, 1896, «Antas e castros do Concelho de Alijó», AP, I série, 2, Lisboa, 1896, pp. $264-266$

Calo Lourido, 1993, Francisco Calo Lourido - A Cultura Castrexa, Historia de Galicia, 3, Vigo, 1993

CARDOzo, 1747, Luiz Cardozo - Diccionario Geographico, 1, Lisboa, 1747

CARrocera, 1990, F. Carrocera Fernández - «El castro de San Isidro: informe de las excavaciones arqueológicas 1986», Excavaciones Arqueológicas en Asturias. 1983-86, Oviedo, 1990, pp. 157-162

Castro Lopo, 1954, Joaquim de Castro Lopo - O Concelho de Valpaços, Lourenço Marques, 1954

Centeno, 1987, Rui Centeno - A Circulação Monetária no Noroeste de Hispânia até 192, Porto, 1987

Costa, 1968, J. Gonçalves da Costa - Montalegre e Terras do Barroso, Montalegre, 1968

Cruz, 1897, Belchior da Cruz - «Museu Municipal de Bragança», AP, 3, Lisboa, 1897, pp. $155-156$ e 244

Delibes, 1980, G. Delibes de Castro - «Un presunto depósito del Bronce Final del Valle de Vidríales (Zamora)», TP, 37, Madrid, 1980, pp. 221-246

Conimbriga, 39 (2000) 5-51 
ERvedosa, 1967-68, Carlos Ervedosa - «O Castro de Sabrosa», TAE, 20 (3-4), Porto, 1967-68, pp. 355-367

ERvedosa, 1981, Carlos Ervedosa - «Campanha arqueológica no Castro de Sabrosa em Setembro de 1980», TAE, 24 (1), Porto, 1981 pp. 147-151

Ervedosa, 1982, Carlos Ervedosa - «Campanha de trabalhos no Castro de Sabrosa - 1981», TAE, 24 (2), Porto, pp. 351-359

Ervedosa, 1983, Carlos Ervedosa - «Campanha de trabalhos no Castro de Sabrosa em 1982», TAE, 24 (3), Porto, 1983, pp. 519-525

ERvedosa, 1984, Carlos Ervedosa - «Campanha de trabalhos no Castro de Sabrosa em 1983», TAE, 24 (4), Porto, 1984, pp. 685-688

ERvedosA, 1985a, Carlos Ervedosa - «Ara votiva a Júpiter encontrada em Sabrosa», TAE, 25 (1), Porto, 1984, pp. 165-170

ERvedosa, 1985b, Carlos Ervedosa - «Sabrosa. Castro de Sabrosa - 1982 e 1983», Informação Arqueológica, 5, Lisboa, 1985, p. 141

ERvedosa, 1985, Carlos Ervedosa - «Campanha de trabalhos no Castro de Sabrosa em 1984», TAE, 25 (1), Porto, 1985, pp. 163-164

EsCribano VelasCo, 1990, Consuelo Escribano Velasco - «Contribución al estudio de la Edad del Hierro en el Noroeste de Zamora: el "Castillo", Manzanal de Abajo», I Congreso de Historia de Zamora, tomo II, Zamora, 1990, pp. 211-224

ESPARZA ARRoYo, 1980, Angel Esparza Arroyo - «Nuevos castros com piedras hincadas en el borde occidental de la Meseta», Actas do Seminário de Arqueologia do Noroeste Peninsular, II, Guimarães, 1980, pp. 71-83

Esparza Arroyo, 1986, Angel Esparza Arroyo - Eos castros de la Edad del Hierro del Noroeste de Zamora, Zamora, 1986

Esparza Arroyo, 1995, Angel Esparza Arroyo - «La Primera Edad del Hierro», Historia de Zamora, I, Zamora, 1995

FernándeZ-Posse e SÁnchez Palencia, 1997, M. Dolores Fernández-Posse e F.-Javier Sánchez Palencia - «Ocupación del territorio y estructura social en las poblaciones castreñas astures», O I Milénio a. C. no Noroeste Peninsular; a Fachada Atlántica e o Interior (A. Redentor, ed.), Bragança, 1997, pp. 87-106.

FigueIREDO, 1895-1896, A. M. Figueiredo - «Informações arqueológicas recolhidas no Diccionário Geographico de Cardoso», AP, 1, 1885, pp. 142-144, 241-243, 316$-320 ; 2,1896$, pp. 162-165

FonTES, 1992, Luís Fernando de Oliveira Fontes - Carta Arqueológica do Concelho de Montalegre, Braga, 1992 (policopiado)

Freitas e SANTOS JÚNIOR, 1980, Adérito M. Freitas e Joaquim dos Santos Júnior «O Castro da Curalha. $5^{\text {a }}$ campanha de escavações - 1979», TAE, 23 (4), Porto, 1980, pp. 393-405

Freitas e SANTOS JúNIOR, 1981, Adérito M. Freitas e Joaquim dos Santos Júnior «O Castro da Curalha. 6a campanha de escavações - 1980», TAE, 24 (1), Porto, 1981, pp. 59-86

Freitas e SANTOS JÚNIOR, 1982, Adérito M. Freitas e Joaquim dos Santos Júnior «O Castro da Curalha. 7a campanha de escavações - 1981», TAE, 24 (2), Porto, 1982, pp. 265-291

Conimbriga, 39 (2000) 5-51 
Freitas e SAntos JúnIOR, 1983, Adérito M. Freitas e Joaquim dos Santos Júnior «O Castro da Curalha. 8a campanha de escavações - 1982», TAE, 24 (3), Porto, 1983, pp. 453-474

Freitas e Santos JúnIOR, 1984, Adérito M. Freitas e Joaquim dos Santos Júnior «O Castro da Curalha. 9a campanha de escavações - 1983», TAE, 24 (4), Porto, 1984, pp. 589-617

GARCÉs e JUNYENT, 1989a, Ignasi Garcés Estallo e Emili Junyent Sanchez - «Fortificación y defensa en la I Edad del Hierro. Piedras Hincadas en Els Vilars», Revista de Arqueologia, X, 93, (Janeiro) 1989, pp. 38-49

GARCÉs e JunYENT, 1989b, Ignasi Garcés Estallo e Emili Junyent Sanchez - «El poblado fortificado de los Campos de Urnas Tardios en Els Vilars, Arbeca, Lleida», XIX Congreso Nacional de Arqueología, II, Zaragoza, 1989, pp. 329-339

GómEZ Moreno, 1904, Manuel Gómez Moreno - «Sobre arqueología primitiva en la región del Duero», BRAH, XLV, Madrid, 1904, pp. 147-160

GonçALVES, 1992-93, Antonio A. Huet Bacelar Gonçalves - «Contribuição para o inventário arqueológico do concelho de Sabrosa - Distrito de Vila Real», Portugalia, Nova série, XII-XIV, Porto, pp. 173-217

HARBINSON, 1967-68, Peter Harbinson - «Castros with "pedras fincadas" in Trás-osMontes», TAE, 20, Porto, 1967-1968, pp. 385-389

HARBINSON, 1968, Peter Harbinson - «Castros with chevaux-de-frise in Spain and Portugal», Madrider Mitteilungen, 9, Madrid, 1968, pp. 116-147

HARBInson, 1971, Peter Harbinson - «Wooden and Stone Chevaux de Frise in Central and Western Europe», Proceedings of the Prehistoric Society, 37, 1971, pp. $195-$ $-225$

Hóck e Coelho, 1972, Martin Hõck e Luís Coelho - «Materiais metálicos da colecção arqueológica do Museu Abade de Baçal em Bragança», $A P$, $3^{\text {a }}$ s., 6, Lisboa, 1972, pp. 219-251

HogG, 1957, A. H. A. Hogg - «Four Spanish Hill-forts», Antiquity, XXXI, 1957, pp. 25$-32$.

HogG, 1975, A. H. A. Hogg - Hill-forts of Britain, Londres, 1975.

KALB, 1980, Philine Kalb - «Zur Atlantichen Bronzezeit in Portugal», Madrider Mitteilungen, 58, 1980, pp. 25-59

Lemos, 1993, Francisco Sande Lemos - O Povoamento Romano de Trds-os-Montes Oriental, Tese de doutoramento policopiada, Braga, 1993

Lemos, 1995, Francisco Sande Lemos - «Zoelas e Civitas Zoelarum: uma unidade étnica no quadro da romanização do Noroeste», TAE (Actas do l. ${ }^{\circ}$ Congresso de Arqueologia Peninsular, VI), 35 (2), Porto, pp. 293-306

Lemos, 1996, Francisco Sande Lemos - «Povoamento, espaço e gentilitates no I milénio a. C. no Nordeste transmontano», De Ulisses a Viriato. O Primeiro Milénio a. C, Lisboa, 1996, pp. 147-153

Lemos e Martins, 1982, Francisco Sande Lemos e Manuela Martins - O Castelo Velho de Lagoaça, Braga, 1982 (dact.)

Lopo, 1898, Albino Pereira Lopo - «Vestígios archeológicos de Babe», AP, 4, Lisboa, 1898, pp. 340-343

Conimhriga, 39 (2000) 5-51 
Lopo, 1910, Albino Pereira Lopo - «Urna jornada archeologica», AP, 15, Lisboa, 1910, pp. 328-333

Lopo, 1987, Albino Pereira Lopo - Apontamentos Arqueológicos, Braga, 1987

Lorrio, 1997, Alberto J. Lorrio - Los Celtíberos (Complutum extra-7), Universidad de Alicante/Universidad Complutense, Alicante, 1997

LOURENÇo Fontes, 1978, A. Lourenço Fontes - «Aras romanas», in A. Lourenço Fontes e Carvalho de Moura (eds.), Comemorações do Milenário de São Rosendo (977-1977) em Montalegre e Pitões das Júnias, Montalegre, 1978, pp. 14-24

LuCAS e RuBIO, 1986-87, Maria Rosario Lucas Pellicer e Isabel Rubio de Miguel - «Introducción del caballo como animal de montura en la Meseta: problemática», Zephyrus 3 39-40, 1986-87, pp. 437-444

Luzon NoguÉ et alii, 1980, J. M. Luzón Nogué, F.-J - Sanchez Palencia, F. Acuña Castroviejo, et alii - El Caurel (Escavaciones Arqueológicas en España, 110), Madrid, 1980

Magalhães et alii, 1975, Adolfo A. Magalhães, Francisco Carneiro Júnior e Adérito M. Freitas, O Castro da Curalha. I a campanha de escavações (1974), Braga, 1975

MagalHães et alii, 1977, Adolfo A. Magalhães, Francisco Carneiro Júnior e Adérito M. Freitas, «O Castro da Curalha. 2a e $3^{\text {a }}$ campanhas de escavações - 1975 e 1976», TAE, 23 (1), Porto, 1977, pp. 19-40

Magalhães et alii, 1978, Adolfo A. Magalhães, Francisco Carneiro Júnior e Adérito M. Freitas, «O Castro da Curalha. 4a campanha de escavações - 1977», TAE, 23 (2-3), Porto, 1978, pp. 267-277

Maranhão, 1836, Francisco dos Prazeres Maranhão - Breve Noticia da Terra de Panoyas, Coimbra, 1836

Marcos, 1994, Domingos dos Santos Marcos - «Catálogo dos monumentos e sitios arqueológicos do Planalto Mirandês», Brigantia, 14 (1-2), Bragança, 1994, pp. $97-131$

MARTINS, 1980a, João Baptista Martins - «Seara Velha - memórias antigas», Notícias de Chaves, 18-01-80, Chaves, 1980

Martins, 1980b, João Baptista Martins - «O Castro da Pastoria», Notícias de Chaves, 02-05-80, Chaves, 1980

MARTINS, 1984, João Baptista Martins - Inventário dos sítios com interesse arqueológico do concelho de Chaves, Chaves 1984 (dact.)

MARTINS, 1985, João Baptista Martins - Os castros do concelho de Chaves, Chaves, 1985 (dact.)

Martín Valls, 1971, Ricardo Martin Valls - «EI castro del Picón de la Mora (Salamanca)», BSAA, XXXVII, Valladolid, 1971, pp. 125-139

Miranda JúNIOR et alii, 1983, Avelino Miranda Júnior, Joaquim Norberto dos Santos e Joaquim Santos Júnior - «Castros do concelho de Boticas», TAE, 24 (3), Porto, 1983, pp. 401-451

Miranda JúNIOR et alii, 1985, Avelino Miranda Júnior, Joaquim Norberto dos Santos e Joaquim Santos Júnior — «Os castros do concelho de Boticas - II», Anais da Faculdade de Ciências do Porto, 66 (1-4), Porto, 1985, pp. 5-96 
Montalvão, 1971, Antonio Montalvão - Visitas a castros nos arredores de Chaves, ed. policopiada, Chaves, 1971

MoRET, 1991, Pierre Moret - «Les fortifications de 1'âge du fer dans la Meseta Espagnole: origine et diffusion des techniques de construction», Mélanges de la Casa de Velázquez, XXVII (1), Madrid, 1991, pp. 5-42

Moret, 1996, Pierre Moret - Les fortifications ibériques. De la fin de TAge du Bronze à la conquête romaine, Madrid, 1996

Neto, 1975, Joaquim Maria Neto - O Leste do Territorio Bracarense, Torres Vedras, 1975

Pereira, 1905, Martins Pereira - Terras de Entre Douro e Sabor, Setúbal, 1905

Pérez MACÍAS, 1994, J. A. Pérez Macias - «El yacimiento calcolítico del Cerro del Brueco. Propuestas para una secuencia de la edad del cobre en los Picos de Aroche», Arqueología en el entorno del Bajo Guadiana, Huelva, 1994, pp. 119$-148$

PinheIro, 1895, José Henriques Pinheiro - Estudo da estrada militar romana entre Braga e Astorga..., Porto, 1895

Ponte, 1980, María de La Sálete da Ponte - «A génese das fíbulas do Noroeste peninsular», Actas do Seminário de Arqueologia do Noroeste Peninsular, II, Guimarães, 1980, pp. 111-119

PonTe, 1984, Sálete da Ponte - «Fíbulas de sitios a norte do rio Douro», Lucerna (Homenagem a D. Domingos de Pinho Brandão), Porto, 1984, pp. 111-144

Rodríguez Colmenero, 1977, Antonio Rodríguez Colmenero - Galicia Meridional Romana, Universidad de Deusto, Bilbao, 1977

Romero CARnicero, 1991, F. Romero Carnicero - Los castros de la Edad del Hierro en el Norte de la provincia de Soria, Valladolid, 1991

SAmpaio, 1929, José R. L. Sampaio - «Crasto de Nogueira de Barrozo», Era Nova, 30-06-29 e 14-07-29, Chaves, 1929

SAnches, 1992, María de Jesus Sanches - Pré-história Recente no Planalto Mirandês (Leste de Trás-os-Montes), Porto, 1992

SAntos JúnIOR, 1957, Joaquim dos Santos Júnior - «O Castro de Carvalhelhos», TAE, 16 (1-2), Porto, 1957 , pp. 25-62

SANTOS JÚNIOR, 1959-60, Joaquim dos Santos Júnior - «Rampas de acesso às muralhas do Castro de Carvalhelhos», Boletín de la Comisión de Monumentos de Orense, 20, Orense, 1959-1960, pp. 361-368

SANTOS JÚNIOR, 1963, Joaquim dos Santos Júnior - «Escavações no Castro de Carvalhelhos - Campanha de 1963», TAE, 19 (2), Porto, 1963, pp. 187-193

SANTOS JÚNIOR, 1964, Joaquim dos Santos Júnior - «Escavações no Castro de Carvalhelhos - Campanha de 1964», TAE, 19 (3-4), Porto, 1964, pp. 360-365

SANTOS JÚNIOR, 1966, Joaquim dos Santos Júnior - «Duas campanhas de escavações no Castro de Carvalhelhos (1965-1966)», TAE, 20 (1-2), Porto, 1966, pp. 181-190

SANTOS JÚNIOR, 1969, Joaquim dos Santos Júnior - «Escavações no Castro de Sabrosa em 1968», TAE, 21, Porto, 1969, pp. 384-389

SANTOS JÚNIOR, 1971, Joaquim dos Santos Júnior - «Escavações no Castro de Carvalhelhos - Campanha de 1970», TAE, 22 (1), Porto, 1971, pp. 72-75

Conimbriga, 39 (2000) 5-51 
SANTOS JÚNIOR, 1973, Joaquim dos Santos Júnior - «As notáveis condições de defesa no Castro de Carvalhelhos», TAE, 22 (3), Porto, 1973, pp. 207-219

SAntos JúnIOR, 1975a, Joaquim dos Santos Júnior - «Castro de Carvalhelhos - Campanha de escavações em Agosto de 1975», TAE, 22 (4), Porto, 1975, pp. 559$-566$

SANTOS JÚNIOR, 1975b, Joaquim dos Santos Júnior - «A Cultura dos Berrões no Nordeste de Portugal», TAE, 22 (4), Porto, 1975, pp. 353-516

SANTOS JÚNIOR, 1975C, Joaquim dos Santos Júnior - «Um machado estranho do castro de Sabrosa», TAE, 22 (4), Porto, 1975, pp. 566-569

SANTOS JÚNIOR, 1977, Joaquim dos Santos Júnior - «Castro de Carvalhelhos - Campanha de 1976», TAE, 23 (1), Porto, 1977, pp. 161-167

SANTOS JÚNIOR, 1978, Joaquim dos Santos Júnior - «27a campanha de escavações no Castro de Carvalhelhos (1977)», TAE, 23 (4), Porto, 1978, pp. 323-333

SANTOS JÚNIOR, 1980, Joaquim dos Santos Júnior - «28a campanha de escavações no Castro de Carvalhelhos (1979)», TAE, 23 (4), Porto, 1980, pp. 604-619

SANTOS JÚNIOR, 1981, Joaquim dos Santos Júnior - «29a campanha de escavações no Castro de Carvalhelhos (1980)», TAE, 24 (1), Porto, 1981, pp. 140-147

SANTOS JÚNIOR, 1982, Joaquim dos Santos Júnior - «30a campanha de escavações no Castro de Carvalhelhos (1981)», TAE, 24 (2), Porto, 1982, pp. 249-263

SANTOS JÚNIOR, 1983, Joaquim dos Santos Júnior - «31 a campanha de escavações no Castro de Carvalhelhos (1982)», TAE, 24 (3), Porto, 1983, pp. 511-519

SANTOS JÚNIOR, 1984a, Joaquim dos Santos Júnior - «32a campanha de escavações no Castro de Carvalhelhos (Julho-Agosto 1983)», TAE, 24 (4), Porto, 1984, pp. 673-682

SANTOS JÚNIOR, 1984b, Joaquim dos Santos Júnior - «O Castro da Curalha - Chaves vivente na época suévica?», TAE, 24 (4), Porto, 1984, pp. 683-684

SANTOS JÚNIOR, 1984C, Joaquim dos Santos Júnior - «30 anos de escavações no Castro de Carvalhelhos (Boticas - Vila Real)», Revista de Guimarães, 94, Guimarães, 1984, pp. 411-424

SANTOS JÚNIOR, 1988-89, Joaquim dos Santos Júnior - «Notável ouriçado de pedras fincadas no Castro de Cunhas - Ardaos - Boticas», Boletín Auriense, 18-19, Orense, 1988-1989, pp. 73-78

SAntos JÚnIOR e Freitas, 1985, Joaquim dos Santos Júnior e Adérito M. Freitas «O Castro da Curalha. 10 ${ }^{\text {a }}$ campanha de escavações (Chaves)», TAE, 25 (1), Porto, 1985, pp. 5-29

SoARes, 1986, Antonio Monge Soares - «O povoado do Passo Alto. Escavações de 1984», Arquivo de Beja, III, 2a série, Beja, 1986, pp. 89-99

SoEIro, 1985-86, Teresa Soeiro - «Muro da Pastoría, Chaves. Campanha de escavação de 1982-83», Portugalia, Nova Série, 6-7, Porto, 1985-1986, pp. 21-28

Silva, 1986, Armando Coelho F. da Silva - A Cultura Castreja no Noroeste de Portugal, Paços de Ferreira, 1986

Taboada Chivite, 1955, J. Taboada Chivite - «Carta arqueológica de la comarca de Verín», III Congreso Nacional de Arqueología (Galicia, 1953), Zaragoza, 1955, pp. 333-352

Conimbriga, 39 (2000) 5-51 
Taracena, 1929, B. Taracena Aguirre - Excavaciones en las provincias de Soria y Logroño. Memoria de las excavaciones practicadas en 1928 (MemJSEA, 103), Madrid, 1929

Tranoy, 1981, Alain Tranoy - La Galice Romaine, París 1981

VASCONCELOS, 1895, José Leite de Vasconcelos - «Noticia de antiguadlas da Terra de Miranda no século XVIII», $A P$, 1, Lisboa, 1895, pp. 11-12

VASCONCELOS, 1903, José Leite de Vasconcelos - «Antiguidades do Concelho de Miranda do Douro», $A P$, 8, Lisboa, 1903, pp. 79-83

Vasconcelos, 1917, José Leite de Vasconcelos - «Por Trás-os-Montes», AP, 22 (1-12)

Lisboa, 1917, pp. 1-53

Veloso Martins, 1978, A. Veloso Martins - Monografia de Valpaços, Famalicão, 1978

- 1968, «Trabalhos arqueológicos no Castro de Sabrosa», Jornal de Notícias, 06-08-1968, (in: AP, série III, 2, pp. 202-203)

\section{ABREVIATURAS:}

AP O Arqueólogo Português. Lisboa.

BRAH Boletín de la Real Academia de la Historia. Madrid.

BSAA Boletín del Seminario de Arte y Arqueologia. Valladolid.

MemJSEA Memorias de la Junta Superior de Excavaciones Arqueológicas. Madrid.

TAE Trabalhos de Antropologia e Etnologia. Porto.

TP Trabajos de Prehistoria. Madrid. 


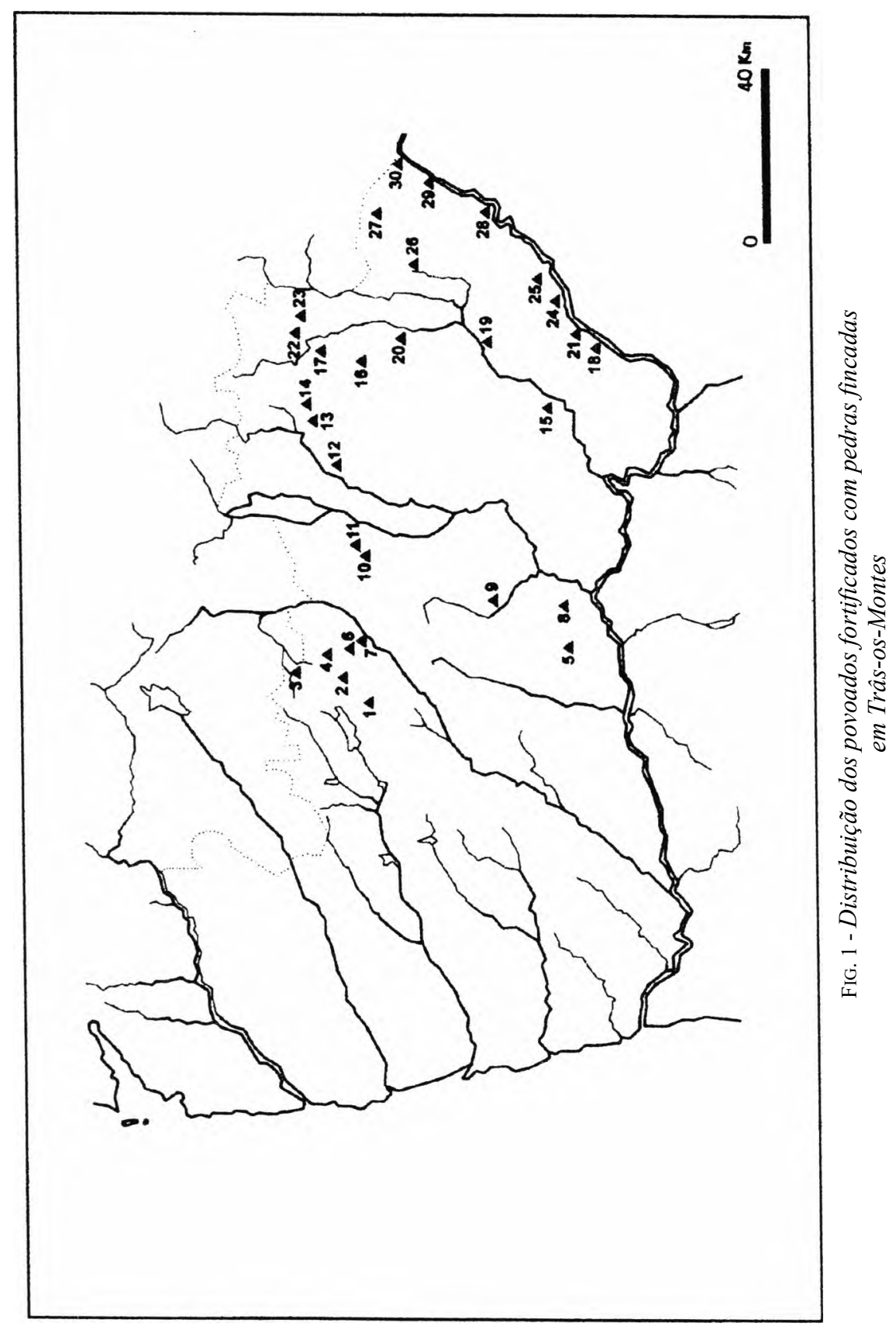




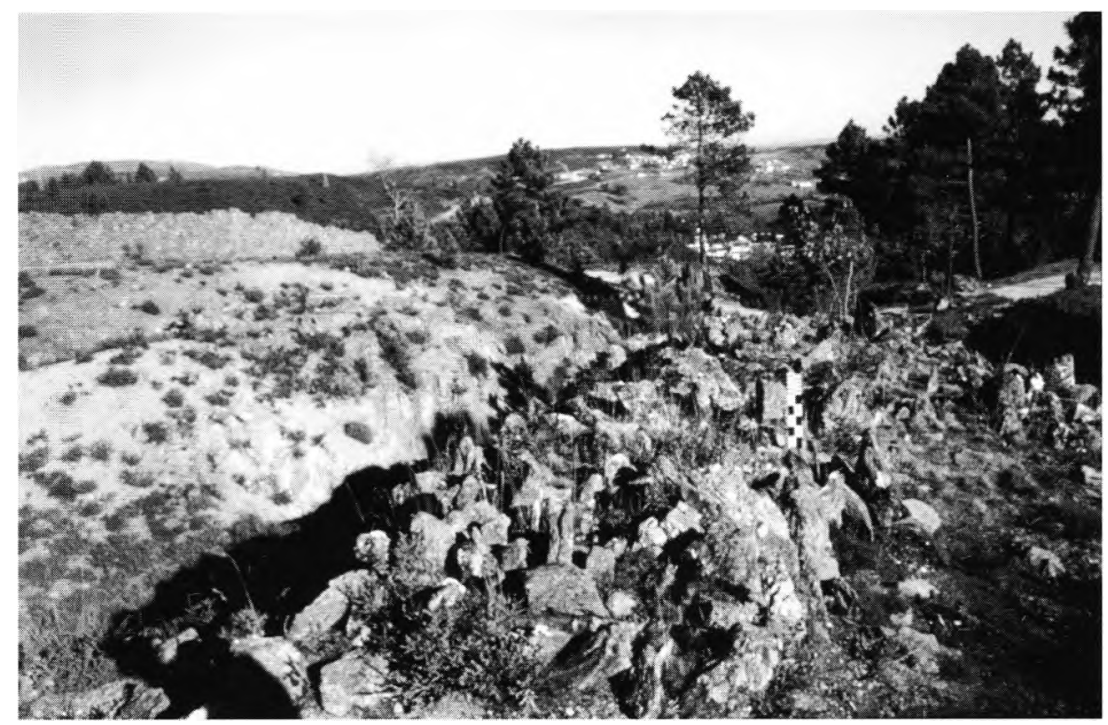

Fото 1 - Castro de Carvalhelhos: barreira de pedras fincadas, fossos e muralha

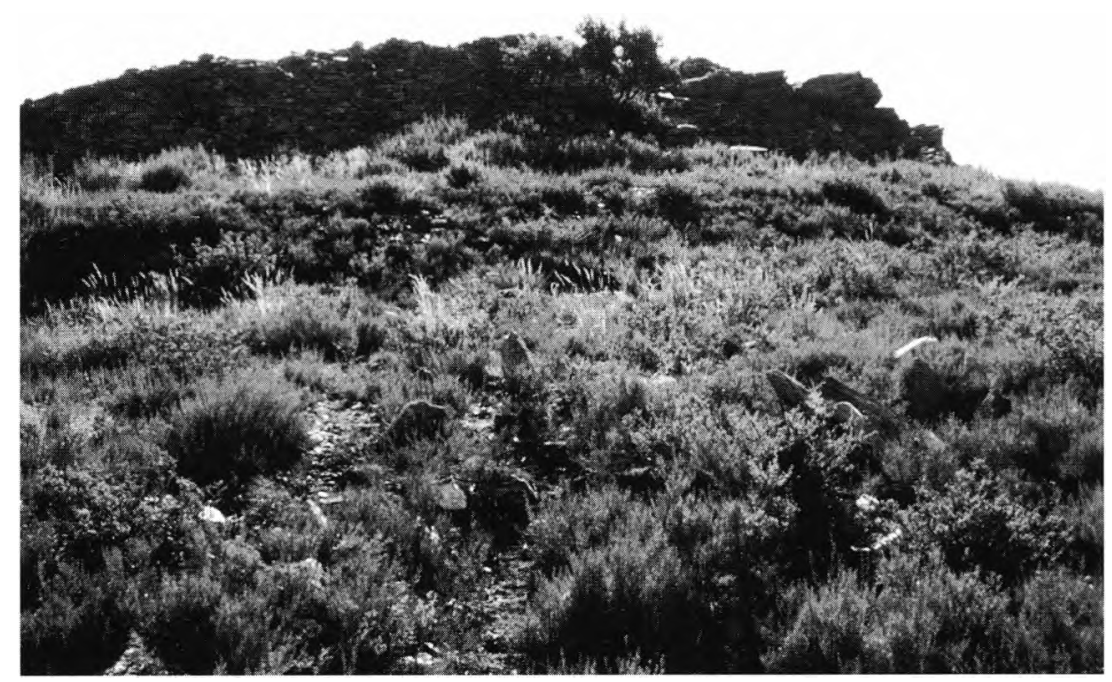

Fото 2 - Castelo dos Mouros de Vale de Égua: campo de pedras fincadas, terrapleno superior e muralha 


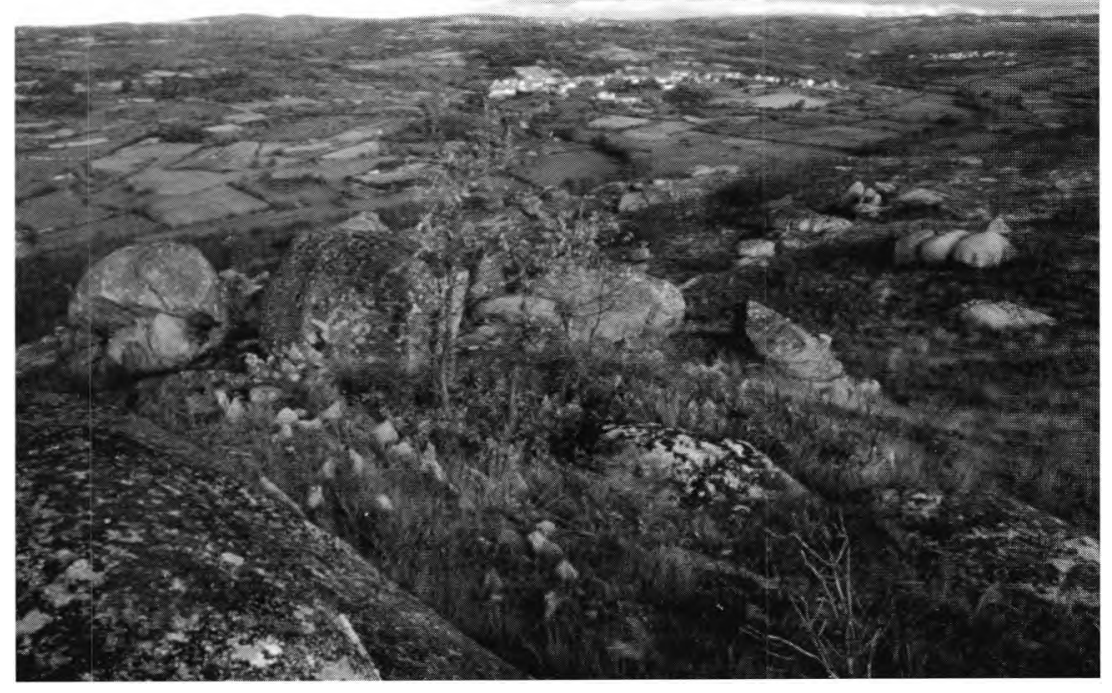

Fото 3 - Murada de Fiães: campo de pedras fincadas entre afloramentos graníticos

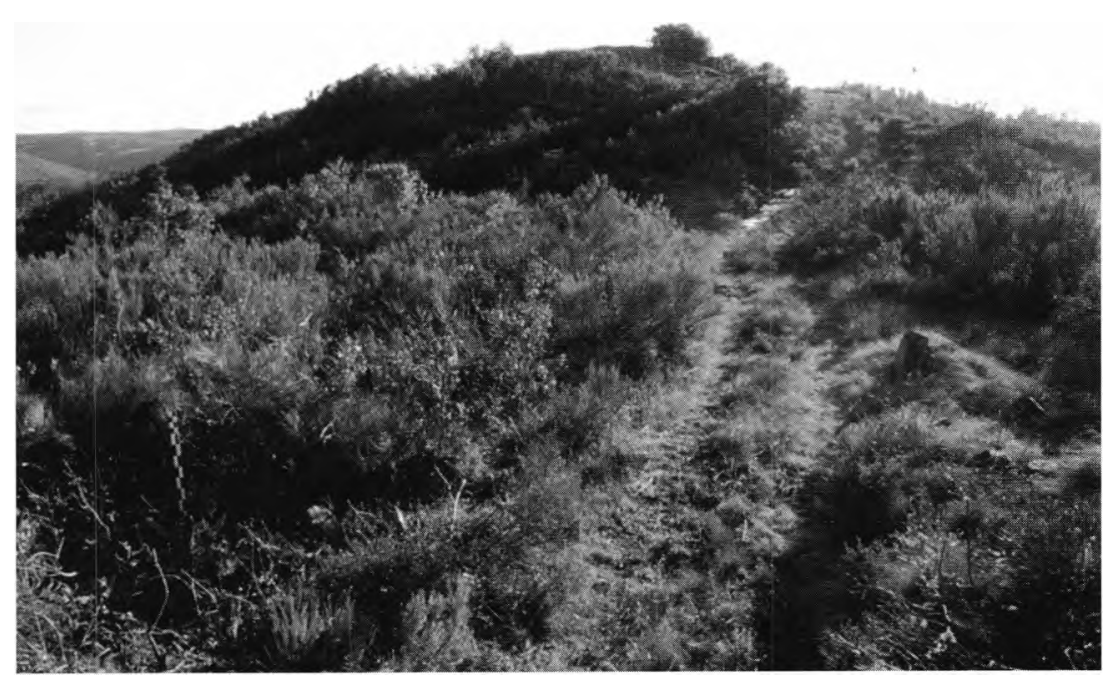

Fото 4 - Monte de Santa Comba de Ousilhão: vestígios do campo de pedras fincadas, fosso, parapeito e muralha 


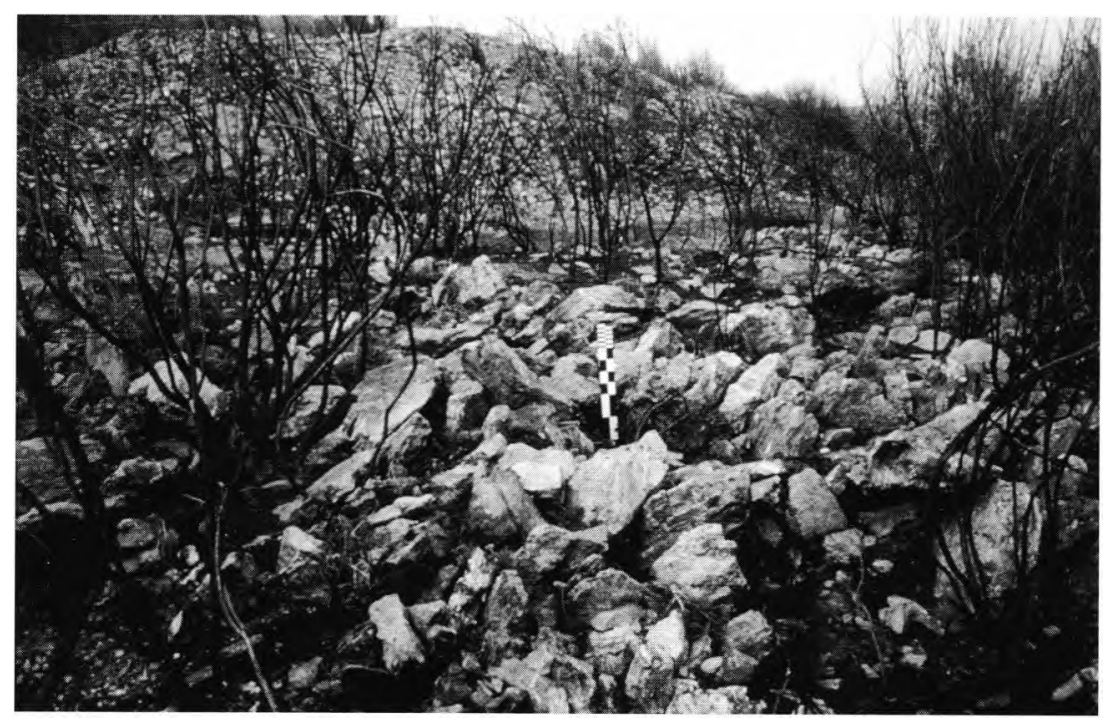

Fото 5 - Castro de Babe: aspecto da barreira de pedras fincadas e da destruição sofrida pela muralha

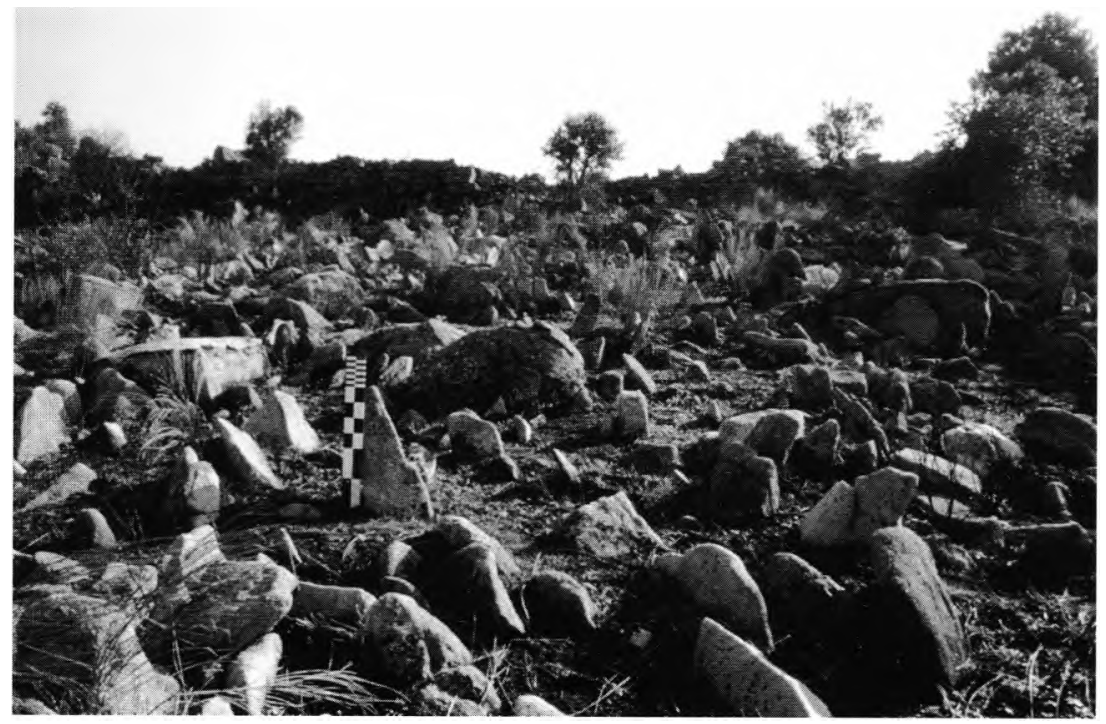

Foто 6 - Cigaduenha de Picote: campo de pedras fincadas e muralha 